\title{
Teknologi Augmented Reality Pada Promosi Berbasis Android
}

\author{
Yuli Cahyaningsih \\ Universitas Amikom Purwokerto, Jl. Letjend Pol. Soemarto, Watumas, Purwanegara, Kec. Purwokerto Utara, Kabupaten \\ Banyumas, Jawa Tengah 53127, Indonesia \\ yulicahayaningsih@gmail.com
}

\section{NF O A R T I K E L}

Article History:

Received Maret 1, 2020

Revised June 21, 2020

Accepted July 12, 2020

Available Online August 5, 2020

\section{Keywords:}

Augmented Reality,

Promotional Media,

Android,

MDLC

\section{Kata Kunci:}

Augmented Reality,

Media Promosi,

Android,

$M D L C$

Correspondence:

Telephon: +62 85951218906

E-mail:

yulicahayaningsih@gmail.com

\section{ABSTRACT}

Technological advances can be applied in the business world as a medium of promotional media. Augmented Reality $(A R)$ is a technology that combines 2 dimensions and 3 dimensions, then projecting the virtual objects in real-time. Augmented Reality can be utilized in a variety of needs, one of which is the utilization of promotional Media on the Honda Genio brochure. The purpose of this research is to develop new interactive media in assisting the promotion media in Astra Motor Majenang with Android-based Augmented Reality technology. The methods used are MDLC (Multimedia Development Life Cycle) consisting of six stages, the concept, the design, the material collecting, the assembly, testing, and the distribution. The result of this research is an Android-based Augmented Reality promotional media app on the Honda Genio brochure that can display $3 D$ motor objects and display specs in both text and audio form. The conclusion of the study was from the test results Alpha Test system developed spared from disability or failure of use. As for test results Beta Test, 91.2\% of respondents answered strongly agree that it shows that the Augmented Reality app as a promotional medium on the Androidbased Honda Genio brochure is very interesting and acceptable for users.

\section{ABSTRAK}

Kemajuan teknologi dapat diaplikasikan dalam dunia bisnis sebagai sarana media promosi. Augmented Reality (AR) adalah teknologi yang menggabungkan 2 dimensi dan 3 dimensi, kemudian memproyeksikan benda-benda maya tersebut dalam waktu nyata. Augmented Reality dapat dimanfaatkan dalam berbagai kebutuhan, salah satunya adalah pemanfaatan media promosi pada brosur Honda Genio. Tujuan dari penelitian ini adalah untuk mengembangkan media baru yang interaktif dalam membantu media promosi di Astra Motor Majenang dengan teknologi Augmented Reality berbasis Android. Metode yang digunakan adalah MDLC (Multimedia Development Life Cycle) yang terdiri dari enam tahap yaitu pengonsepan (concept), perancangan (design), pengumpulan materi (material collecting), pembuatan (assembly), pengujian (testing), dan pendistrribusian (distribuiton). Hasil dari penelitian ini adalah sebuah aplikasi media promosi Augmented Reality berbasis Android pada brosur Honda Genio yang dapat menampilkan objek 3D motor dan menampilkan spesifikasi dalam bentuk teks dan audio. Kesimpulan dari penelitian ini adalah dari hasil pengujian Alpha Test sistem yang dikembangkan terhindar dari cacat atau kegagalan penggunaan. Sedangkan dari hasil pengujian Beta Test, 91,2\% responden menjawab sangat setuju hal ini menunjukan bahwa aplikasi Augmented Reality sebagai media promosi pada brosur Honda Genio berbasis Android sangat menarik dan dapat diterima oleh pengguna.

\section{Pendahuluan}

Perkembangan teknologi informasi yang kian pesat, tingkat persaingan bisnis yang kian tinggi, dan tuntutan pelanggan yang kian berkembang telah membuat hampir semua perusahaan tergantung pada teknologi [1]. Salah satu teknologi yang berkembang saat ini yang banyak diterapkan pada dunia bisnis yaitu teknologi Augmented Reality (AR)[2].

Augmented Reality atau Realitas Tambahan adalah penggabungan sebuah teknik benda maya dua dimensi maupun tiga dimensi ke dalam sebuah lingkup nyata tiga dimensi kemudian memproyeksikan benda-benda maya tersebut dalam waktu nyata. Dalam kehidupan sehari-hari, Augmented Reality juga sudah mulai 
mendominasi pasar dunia. Salah satu dari kegunaan AR adalah sebagai sarana berbisnis. Banyak perusahaan yang mulai menggunaan AR sebagai media promosi produk mereka [3][4].

Berdasarkan dari penelitian terdahulu, sudah pernah diterapkan teknologi Augmented Reality sebagai media pemasaran. Salah satunya yaitu penelitian yang telah dilakukan oleh [5], telah membuat Augmented Reality pada brosur Yamaha sebagai media promosi. Permasalahan yang dihadapi yaitu ketika konsumen yang ingin membeli motor, konsumen akan melihat terlebih dahulu motor yang akan di beli, jika motor sedang tidak tersedia, maka sebagai alternatifnya menggunakan brosur untuk memberikan informasi visual terhadap motor yang akan dibeli, namun tampilan pada brosur masih menggunakan tampilan yang biasa. Tujuan penelitian tersebut adalah untuk mengembangkan media baru dalam kegiatan promosi pada motor Yamaha Tjahaja Baru menggunakan teknologi Augmented Reality berbasis android. Penelitian ini menghasilkan penerapan Augmented Reality berbasis android pada brosur, sehingga brosur tersebut akan menampilkan objek 3D dari motor, mengganti variasi motor dan mampu menampilkan informasi dari masing-masing motor. Kesimpulan dari penelitian tersebuat adalah aplikasi Augmented Reality tersebut dapat menjadi sarana promosi baru showroom Yamaha Tjahaja Baru. Dengan aplikasi Augmented Reality menggunakan objek 3D pada brosur Yamaha Tjahaja Baru yang menarik, dapat menampilkan bentuk fisik dari motor secara 3D tanpa harus melihat motor secara langsung. Dengan aplikasi Augmented Reality dapat menjadi media baru dalam memberikan visualisasi produk dari Yamaha kepada konsumen.

Kelebihan lain dari Augmented Reality yaitu dapat diimplementasikan secara luas dalam berbagai media. Sebagai aplikasi dalam sebuah smartphone, dalam bingkisan sebuah produk bahkan media cetak seperti buku, majalah, atau koran. Dengan kelebihan tersebut, Augmented Reality memiliki banyak peluang untuk terus dikembangkan, salah satunya dalam bidang media promosi berjenis brosur [6][7]. Brosur adalah sebuah wadah atau sarana yang berisi informasi lengkap yang menggambarkan suatu objek informasi. Dalam hal ini brosur umumnya memberikan informasi berupa text dan gambar dari objek informasi [8][9].

Media promosi seperti brosur sudah biasa digunakan oleh perusahaan yang ingin memperomosikan produk mereka. [10]. Seperti halnya yang dilakukan oleh sebuah perusahaan Astra Motor Majenang. Astra Motor (PT Astra Internasional Tbk Honda Sales Operation), merupakan salah satu Corporate Operation PT Astra Internasional Tbk yang bergerak di bidang distribusi dan penjualan retail kendaraan roda dua merk Honda. Dalam melakukan pemasaran/promosi produk, perusahaan Astra Motor tersebut menggunakan sebuah brosur. Dalam melakukan promosinya, perusahaan tersebut melakukan event dan kegiatan langsung dengan cara mendatangi salah satu rumah warga menggunkan brosur. Namun, permasalahan yang terjadi adalah media promosi yang digunakan itu membuat konsumen tidak dapat mengetahui bagaimana gambar (bentuk) yang cukup detail dari spesifikasi motor tersebut. Maka hal ini menjadi salah satu kekurangan dari brosur tersebut.

Penelitian ini bertujuan untuk membuat aplikasi teknologi Augmented Reality pada brosur Honda Genio berbasis Android untuk menunjang media promosi di Astra Motor Majenang, untuk menunjang media promosi menjadi lebih inovatif, interaktif dan dapat membuat promosi yang lebih menarik bagi konsumen terhadap produk yang ditawarkan. Tahapan yang membangun sistem ini meliputi marker yang berfungsi untuk memanggil model 3D motor agar muncul di layar smartphone/android dengan menggunakan Unity dan Vuforia. Vuforia merupakan sebuah plugin dari software yang bernama Unity 3D. Metode yang digunakan yaitu metode marker augmented reality.

Menurut Rumajar [11], Augmented Reality dibagi menajdi 2 metode yaitu: Marker Based Tracking dan Markerless Augmented Reality. Marker Based Tracking merupakan salah satu metode yang sudah lama dikembangkan sejak 1980-an dan awal 1990-an mulai dikembangkan untuk penggunaan Augmented Reality. Sedangkan Markerless Augmented Reality, perkembangan terbaru marker ini merupakan salah satu metode sebagai objek yang dideteksi. Dengan adanya metode Markerless Augmented Reality, maka penggunaan marker sebagai tracking object yang selama ini menghabiskan ruang, akan digantikan dengan gambar, atau permukaan apapun yang berisi dengan tulisan, logo, atau gambar sebagai tracking object (objek yang dilacak) agar dapat langsung melibatkan objek yang dilacak tersebut. Sehingga dapat terlihat hidup dan interaktif, juga tidak lagi mengurangi efisiensi ruang[12]. 


\section{Method}

Metode yang digunakan untuk pengembangan sistem pada penelitian ini adalah Multimedia Development Life Cycle (MDLC), metode ini adalah metode pengembangan multimedia yang bersumber [13], yang terdiri dari enam tahapan yaitu concept (pengkonsepan), desaign (perancangan), material collecting (pengumpulan materi), assembly (pembuatan), testing (pengujian) dan distribution (pendistribusian). Adapun tahapan-tahapan yang harus dilalui dalam metode MDLC (Multimedia Development Life Cycle), yaitu:

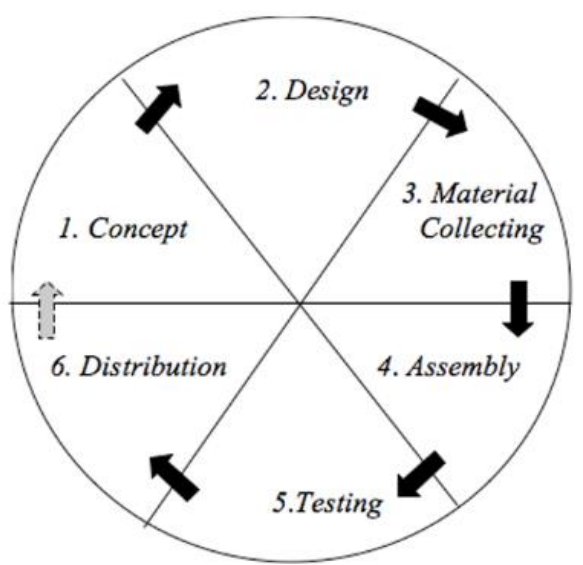

Gambar 1. Tahapan Pengembangan MDLC [13]

Berikut tahapan pengembangan MDLC:

a) Concept (Pengkonsepan)

Fase ini menentukan tujuan dan siapa pengguna program (identifikasi audien). Tujuan dan pengguna akhir program berpengaruh pada nuansa multimedia bentuk pencerminan dari indentitas organisasi yang menginginkan informasi sampai pada pengguna akhir. Karakteristik pengguna termsuk kemampuan pengguna juga perlu dipertimbangkan karena dapat mempengaruhi pembuatam desain. Tahap ini juga akan menentukan jenis aplikasi, tujuan aplikasi. Dasar aturan untuk perancangan juga ditentukan pada tahap ini, misalnya ukuran aplikasi, dan target yang akan menggunakannya. Output dari tahap ini biasanya berupa dokumen bersifat naratif untuk mengungkapkan tujuan proyek yang ingin dicapai.

b) Design (Perancangan)

Fase ini peneliti melakukan konsep perancangan yang selanjutnya akan menjadi dasar dalam pembuatan perancangan yang akan dibuat untuk pemanfaatan Augmented Reality ini, yaitu tahap pembuatan spesifikasi dari arsitektur program, gaya, tampilan dan kebutuhan material atau bahan untuk program. Spesifikasi dibuat serinci mungkin sehingga pada tahap berikutnya, yaitu material collecting dan assemly, pengambilan keputusan baru tidak diperlukan lagi, cukup menggunakan keputusan yang sudah ditentukan pada tahap ini, pada praktiknya, pengerjaan proyek pada tahap awal masih akan sering mengalami penambahan bahan atau pengurangan bagian aplikasi, atau perubahan-perubahan lain. Tahap design menggunakan stroryboard untuk menggambarkan deskripsi pada setiap scene, dengan menggambarkan / menjelaskan semua objek multimedia dan tautan kedalam scene.

c) Material Collecting (Pengumpulan Materi)

Fase ini peneliti mengumpulkan bahan-bahan atau data pendukung untuk penelitian ini dengan cara survey dan melakukan wawancara terhadap perusahaan Astra Honda Motor untuk mendapatkan data yang sesuai dengan kebutuhan yang dikerjakan dalam penelitian ini. Bahan-bahan tersebut antara lain gambar clip art, foto, animasi, video dan audio dan lain-lain.

d) Assembly (Pembuatan)

Pada tahap ini desain yang telah dirancang pada tahap sebelumnya kemudian dibuat sesuai dengan rancangan. Pembuatan aplikasi didasarkan pada tahap design, seperti storyboard, bagan alir, dan 
struktur navigasi dan berpedoman pada teori dan data-data yang berhubungan dengan aplikasi augmented reality berbasis android. Sehingga aplikasi yang dibuat sesuai dengan tujuan yang diharapkan.

Pada tahap ini dimana semua objek atau bahan multimedia dibuat. Pembuatan aplikasi didasarkan pada beberapa tahap, yaitu: pembuatan objek motor, mesin, kerangka motor, spidometer, stop kontak dan bagasi motor.

e) Testing (Pengujian)

Pengujiam dilakukan setelah selesai tahap Assembly. Dengan menjalankan aplikasi atau program dan dengan melihat apakah ada kesalahan atau tidak pada program yang telah dibuat. Pengujian menggunakan 2 metode yaitu pengujian alpha (alpha test) dan selanjutnya akan dilakukan pengujian Beta. Alpha test adalah salah satu strategi pengujian perangkat lunak paling umum digunakan dalam pengembangan perangkat lunak, hal ini khusus digunakan oleh organisasi pengembangan produk dengan tujuan agar system yang dikembangkan terhindar dari cacat atau kegagalan penggunaan.

f) Distribution

Pada tahap ini dimana aplikasi disimpan dalam suatu media penyimpanan. Pada tahap ini jika media penyimpanan tidak cukup untuk menampung aplikasinya, maka dilakukan kompresi terhadap aplikasi tersebut. Tahap builiding final simulasi menjadi aplikasi android smartphone yang akan disimpan pada smartphone android yang digunakan. Peneliti mulai mendemontrasikan aplikasi ke sasaran yaitu masasyarakat umum.

Alasan peneliti menggunakan metode $M D L C$ karena tahapannya jelas, dalam pengerjaannya lebih sederhana, dan pengembangannya cocok untuk membuat media interaktif. Menurut Mustika [14], keenam tahap ini tidak harus berurutan dalam praktiknya, tahap-tahap tersebut dapat saling bertukar posisi. Meskipun begitu, tahap concept memang harus menjadi hal yang pertama kali dikerjakan supaya dapat mempermudah dalam pengujian. Kesimpulannya metode ini yaitu pengerjaannya lebih sederhana dan tahapannya tidak harus berurutan meski tahap concept harus menjadi yang pertama dalam tahap pengerjaan.

Perbandingan pengembangan perangkat lunak multimedia $M D L C$ dengan pengembangan perangkat lunak multimedia lainnya memiliki kelebihan dan kekurangan masing-masing metode. Sehingga hasil metode yang dianalisa mempunyai kesamaan, yaitu secara umum tahapan dilakukan secara sekuensial serta tidak ada metode yang paling baik karena masing-masing mempunyai kelebihan dan kekurangan masingmasing. Pengembangan perangkat lunak multimedia seperti $M D L C$ mempunyai karakteristik yang berbeda dengan perangkat lunak klasik. Hal ini disebabkan multimedia merupakan kombinasi dari elemen teks, gambar diam/foto/seni grafis, suara, animasi, dan video yang dimanipulasi secara digital karakteristik [13].

\section{Results and Discussion}

Metode yang digunakan untuk pengembangan sistem pada penelitian ini adalah MDLC (Multimedia Development Life Cycle), metode ini adalah metode pengembangan multimedia yang bersumber dari [13], yang terdiri dari enam tahapan yaitu: concept (pengkonsepan), design (perancangan), material collecting (pengumpulan bahan), assembly (pembuatan), testing (pengujian) dan distribution (distribusi). Penjelasan tahap dan analisis hasil penelitian ini adalah sebagai berikut:

\subsection{Pengkonsepan (Concept)}

Aplikasi ini bertujuan untuk membuat aplikasi berbasis android menggunakan teknologi Augmented Reality yang dapat digunakan untuk melengkapi media promosi yang interaktif untuk menampilkan gambar (bentuk) detail dari spesifikasi motor Honda Genio di Astra Honda Motor Majenang. Jenis bahan yang dipilih yaitu sebuah brosur sebagai marker dengan bantuan teknologi Augmented Reality. Software yang digunakan yaitu Unity, Vuforia, 3Ds Max dan CorelDraw x7. Aplikasi menggunakan konsep multimarker sehingga dapat menampilkan objek 3D motor Honda Genio, mesin, bagasi, spidometer, stop kontak dan sasis motor. 
Tabel 1. Deskripsi Konsep Media Promosi

\begin{tabular}{ll}
\hline Indikator & \multicolumn{1}{c}{ Keterangan } \\
\hline Judul & Penerapan Teknologi Augmented Reality Pada Brosur Honda Genio Berbasis Android. \\
Tujuan Aplikasi & Membuat aplikasi Teknologi Augmented Reality Pada Brosur Honda Genio Berbasis Android \\
& untuk melengkapi media promosi di Astra Motor Majenang. \\
Audience & Sales atau karyawan Astra Motor Majenang dan pengguna Smartphone Android. \\
Image & Menggunakan format png untuk logo dan Background pada aplikasi dan format jpg dan untuk \\
& marker pada objek motor. \\
Audio & Intrumen dengan format .mp3 \\
Jenis Aplikasi & Aplikasi Augmented Reality dengan marker gambar. \\
Software & 3Ds Max, Unity 3D 2017, Vuforia SDK, Android SDK dan Visual Studio 2012. \\
\hline
\end{tabular}

\subsection{Perancangan (Design)}

Setelah tahap pengkonsepan maka tahap selanjutnya adalah tahap perancangan atau design. Dalam tahap ini dilakukan pembuatan rancangan bentuk tampilan, arsitektur navigasi dan kebutuhan material atau bahan untuk melengkapi media promosi pada motor Honda Genio dengan menggunakan Augmented Reality. Tahap ini dibuat acuan supaya lebih mudah dalam pembuatan atau saat pengoperasian. Dalam perancangan aplikasi ini dibutuhkan software 3Ds Max untuk membuat model motor Honda Genio dalam bentuk tiga dimensi dan Unity yang digunakan untuk mengolah objek motor dan menerapkan teknologi augmented reality-nya. Untuk itu diperkukan Storyboard untuk menggambarkan semua objek multimedia dan tautan ke scene lain, berikut adalah tabel Storyboard bentuk objek yang akan dibuat pada Tabel 2.

Tabel 2. Storyboard

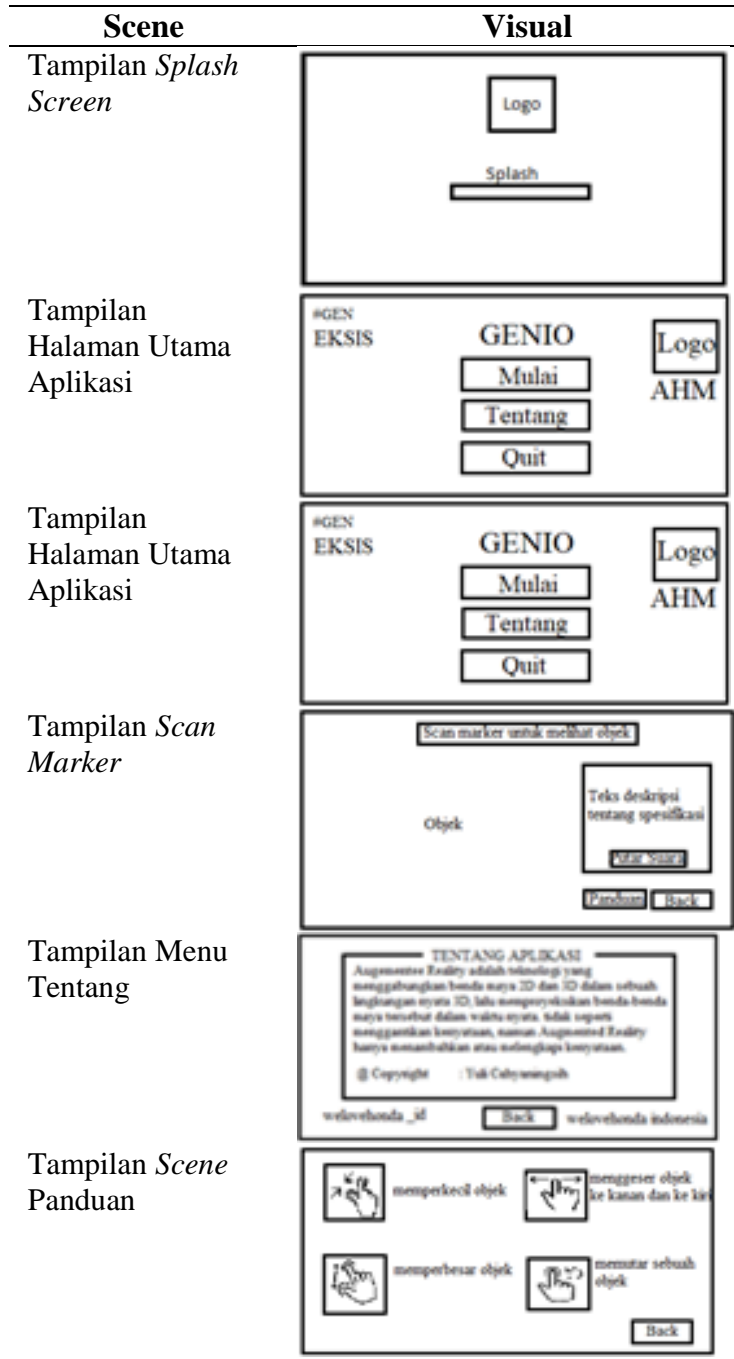

Tampilan Splash Screen adalah tampilan pertama yang muncul ketika aplikasi dijalankan. Splash Screen berupa loading yang akan berfungsi menuju ke tampilan halaman utama aplikasi Augmented Reality.

Tampilan menu ini terdapat logo, tombol mulai, tombol tentang, dan tombol keluar. Tombol mulai berfungsi untuk menuju ke tampilan

Scan Marker pada aplikasi Augmented Reality, tombol tentang berfungsi untuk menuju ke tampilan tentang $A R$ dan pembuat apikasi, dan tombol keluar berfungsi untuk keluar dari aplikasi.

Tampilan Scan Marker ini terdapat Keterangan scan Marker atau gambar untuk mendeteksi dan menampilkan objek 3D motor. Dan terdapat tombol putar suara untuk memutar suara teks deskripsi tentang spesifikasi objek, dan tombol panduan berfungsi untuk memberi tau penggunaan aplikasi.

Tampilan Menu tentang ini berfungsi untuk melihat keterangan tentang $A R$ dan cara dalam menggunakan aplikasi tersebut.

Tampilan scene panduan ini berfungsi untuk mengetahui cara penggunaan aplikasi. 


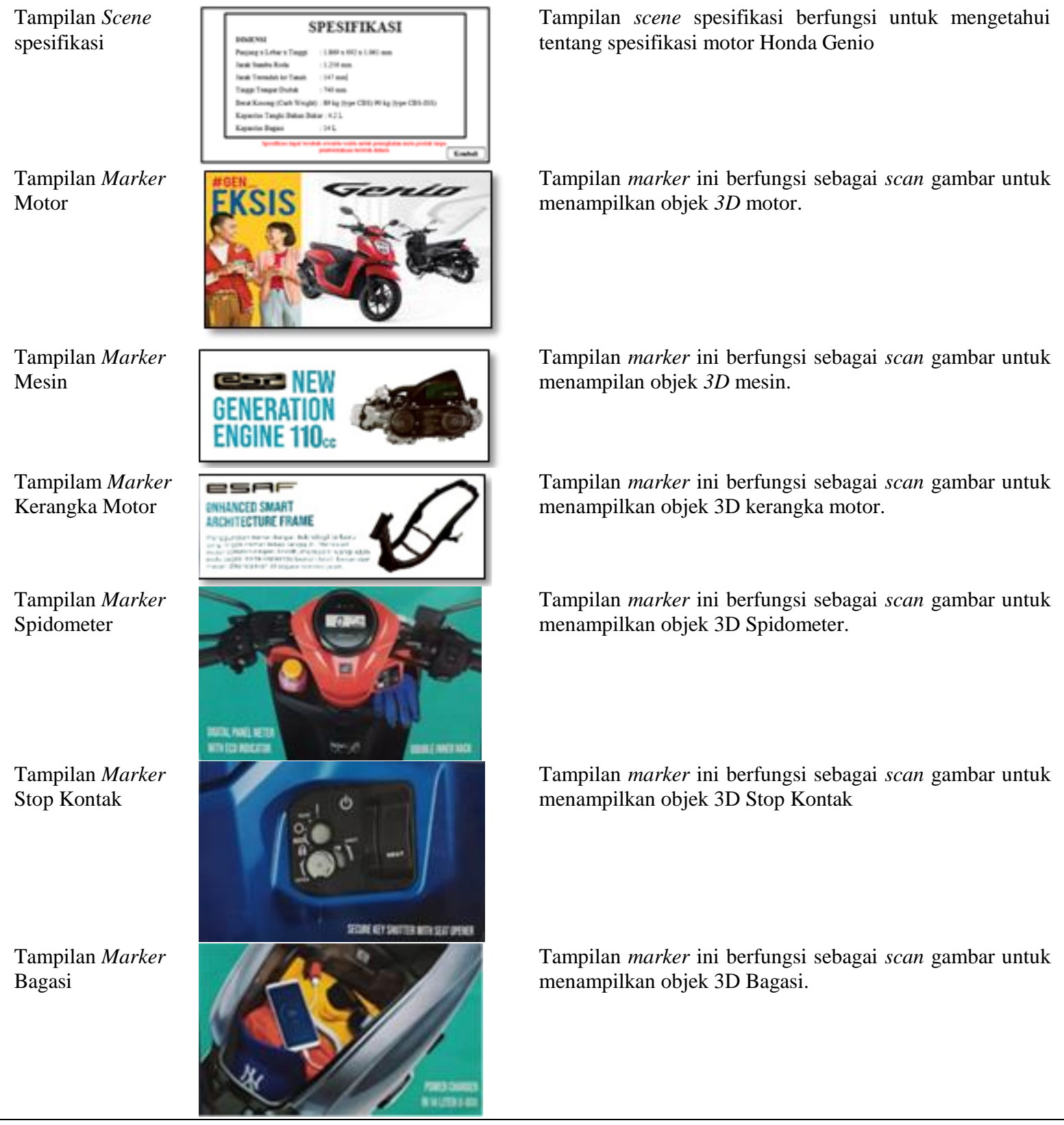

a. Struktur Navigasi

Perancangan struktur navigasi dibuat untuk memudahkan pembuatan aplikasi ini dalam bentuk menumenu pilihan yang akan membawa pengguna ke halaman yang di inginkan dan supaya sesuai dengan alur yang telah dibuat. Gambar berikut merupakan struktur navigasi dari aplikasi AR pada brosur Honda Genio. Rancangan struktur navigasinya aplikasi dapat dilihat pada Gambar 2. 


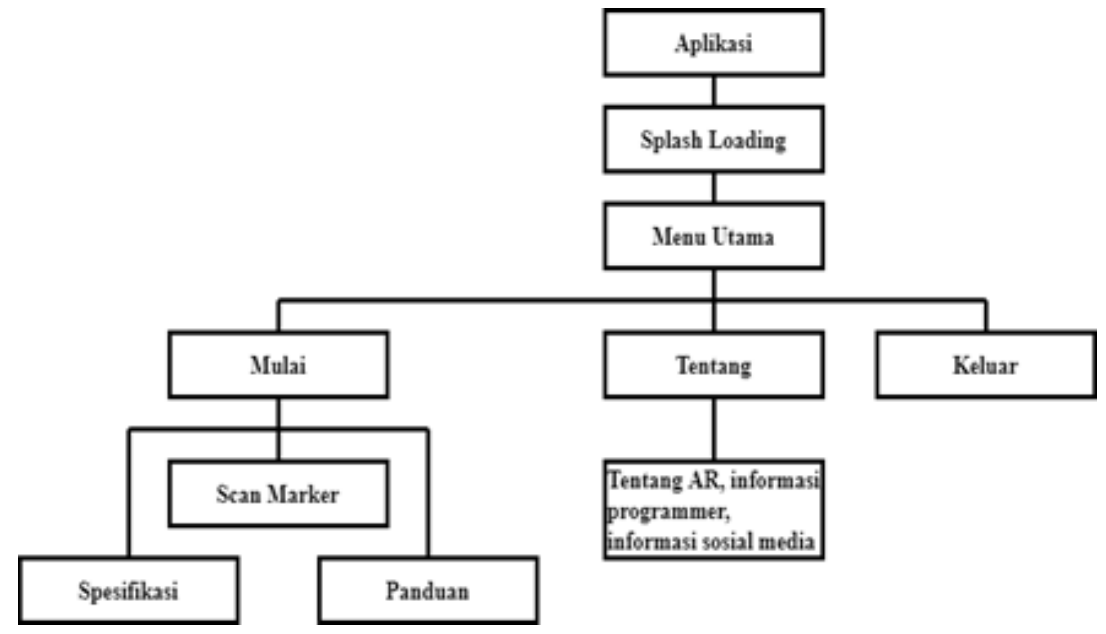

Gambar 2. Struktur Navigasi Aplikasi

Dari hasil Gambar 2. struktur navigasi aplikasi diatas dapat dijelaskan sebagai berikut. Aplikasi ARGenio dimulai dari Splash Loading kemudian akan masuk ke scene menu utama yang terdiri dari Mulai, Tentang dan Quit. Pada tombol Mulai akan masuk ke scene AR-Camera untuk scan marker dan menampilkan objek 3D, didalam scene AR-Camera juga terdapat tombol Panduan yang berfungsi untuk mengetahui tentang penggunaan aplikasi serta tombol putar suara untuk menjelaskan spesifikasi motor dalam bentuk audio atau suara. Kemudian untuk tombol Tentang akan masuk ke scene tentang Augmented Reality, informasi programmer dan informasi media sosial dari Astra Honda Motor. Tombol spesifikasi berfungsi untuk mengetahui tentang spesifikasi motor Honda Genio. Dan tombol Keluar akan keluar dari aplikasi.

\subsection{Pengumpulan Bahan (Material Collecting}

Pada tahap ini peneliti mengumpulkan bahan-bahan atau data pendukung yang diperlukan dalam pembuatan aplikasi ini, berikut adalah tabel yang digunakan dalam pembuatan aplikasi ini:

a. Penanda atau Marker. Penanda digunakan sebagai media untuk mengenali objek motor dan yang lainya, penanda atau marker seperti terlihat pada Tabel 3.

Tabel 3. Penanda atau Marker

\begin{tabular}{|c|c|c|c|c|}
\hline No & Gambar & Ukuran & Jenis & Keterangan \\
\hline 1 & & $5 k b$ & PG & Diunduh dari internet. \\
\hline 2 & & $57 \mathrm{~kb}$ & JPEG & $\begin{array}{l}\text { Diambil dari kamera } \\
\text { android. }\end{array}$ \\
\hline 3 & 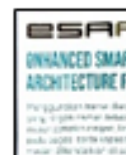 & $66 \mathrm{~kb}$ & JPEG & $\begin{array}{l}\text { Diambil dari kamera } \\
\text { android. }\end{array}$ \\
\hline 4 & & $19 \mathrm{~kb}$ & JPG & $\begin{array}{l}\text { Diambil dari kamera } \\
\text { android. }\end{array}$ \\
\hline
\end{tabular}




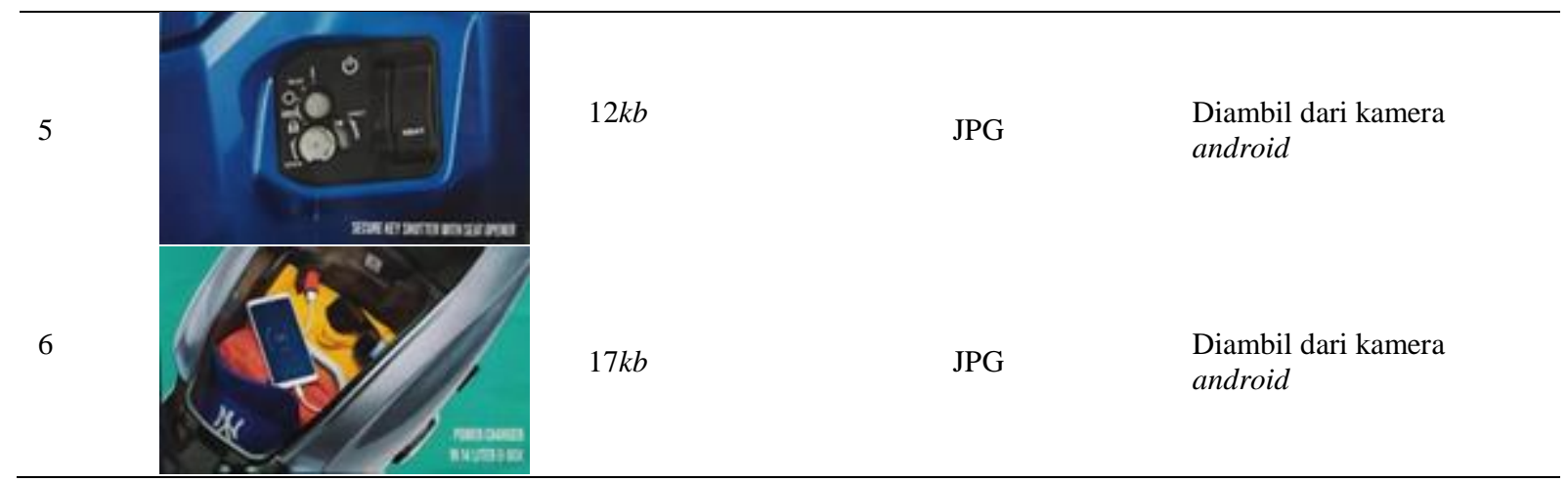

b. Materi atau bahan lainnya. Materi lainnya yang dibutuhkan seperti terlihat pada Tabel 4 .

Tabel 4. Materi Lainnya

\begin{tabular}{|c|c|c|c|}
\hline Gambar & Ukuran & Jenis & Keterangan \\
\hline & $94 k b$ & FBX & Dibuat di $3 D s$ Max \\
\hline & $3,018 \mathrm{~kb}$ & FBX & Dibuat di $3 D s$ Max \\
\hline & $3,018 \mathrm{~kb}$ & FBX & Dibuat di $3 D s$ Max \\
\hline Bagasi & $13,411 k b$ & FBX & Dibuat di $3 D$ Max \\
\hline - Backgroun & & & \\
\hline & $9 k b$ & PNG & Dibuat di $3 D$ Max \\
\hline Button & & & \\
\hline & $36 k b$ & META & $\begin{array}{l}\text { Diunduh dari Asset Store } \\
\text { Unity }\end{array}$ \\
\hline
\end{tabular}




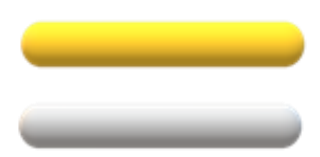

Loading

Logo
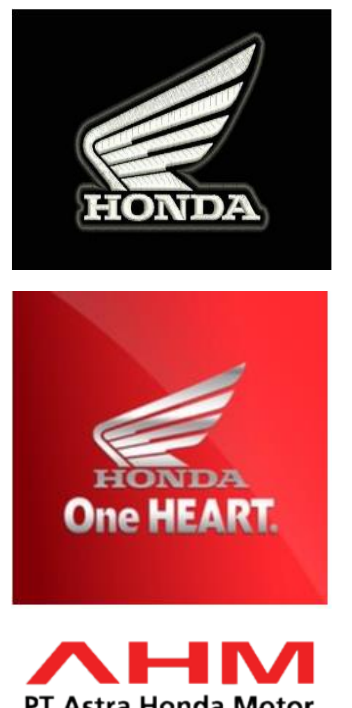

PT Astra Honda Motor

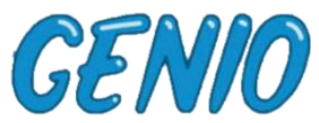

\#GEN

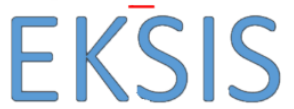

Audio

- Motor

- Mesin

- Kerangka

- Bagasi

- Spidometer

- Stopkontak
$8 k b$

$8 k b$

$P P N G$

Dibuat di 3D Paint

$P P N G$

$P P N G$

$7 \mathrm{~kb}$

$29 k b$

$41 k b$

$P N G$

$P P N G$

$72 k b$

$P P N G$
Diunduh dari internet dan diedit menggunakan $3 D$ Paint.

Diunduh dari internet dan diedit menggunakan $3 D$ Paint.

Diunduh dari internet dan diedit menggunakan $3 D$ Paint.

$\begin{array}{ll}1.06 m b & \mathrm{p} 3 \\ 986 k b & \mathrm{p} 3 \\ 334 k b & \mathrm{p} 3 \\ 327 k b & \mathrm{p} 3 \\ 152 \mathrm{~kb} & \mathrm{p} 3 \\ 114 k b & \mathrm{p} 3\end{array}$

Perekam audio.

p3

p3

p3

p3

\section{Pembuatan (Assembly)}

Pada tahap ini adalah tahap pembuatan aplikasi multimedia berdasarkan perancangan yang telah dibuat sebelumnya. Pada bagian ini yaitu proses membuat objek motor, mesin, kerangka motor, spidometer dan bagasi motor menggunakan 3Ds Max, setelah semua bahan atau material telah dibuat dan dipersiapkan dengan baik berupa gambar, semua di ekspor ke dalam unity $3 D$ yang kemudian dikemas menjadi aplikasi augmented reality. Pada awal aplikasi terdapat beberapa pilihan tombol menu yaitu tombol Mulai untuk menuju pada $A R$ Camera, tombol Tentang untuk mengetahui apa itu tentang Augmented Reality, informasi programmer, dan informasi media sosial dari Astra Honda Motor dan tombol Back untuk menuju ke halaman menu, serta tombol Quit untuk keluar dari aplikasi. Selanjutnya adalah melakukan pembuatan lingkungan Augmented Reality dengan menggunakan software unity $3 D$ selanjutnya bahan atau meterial yang telah dikumpulkan di import ke software unity $3 D$ untuk memulai proses pembuatan aplikasi. Berikut merupakan tahap-tahap pembuatan aplikasi Augmented Reality pada brosur Honda Genio.

\section{a. Pembuatan Objek 3D}

Pembuatan objek 3D merupakan sebuah objek yang akan ditampilkan pada AR-Camera, objek yang akan dibuat adalah objek motor, mesin, kerangka/sasis, spidometer, stopkontak, dan bagasi. Dalam pembuatan objek menggunakan aplikasi 3Ds Max. Dalam permbuatan objek 3D terdapat beberapa tahap proses pembuatan yaitu proses Modelling, Texturing, Lighting dan Rendering. Berikut penjelasannya: 


\section{1) Modelling}

Modelling merupakan proses pebuatan objek. Software yang digunakan peneliti untuk membuat modelling adalah Autodesk 3Ds Max 2014. Alasan peneliti menggunakan software 3Ds Max karena dalam pmbuatan modelling lebih mudah. Model tersebut biasanya dibentuk dari objek geometry pada software, namun dapat juga dibentuk dengan objek lain seperti line, circle, rectangle dan lainnya.

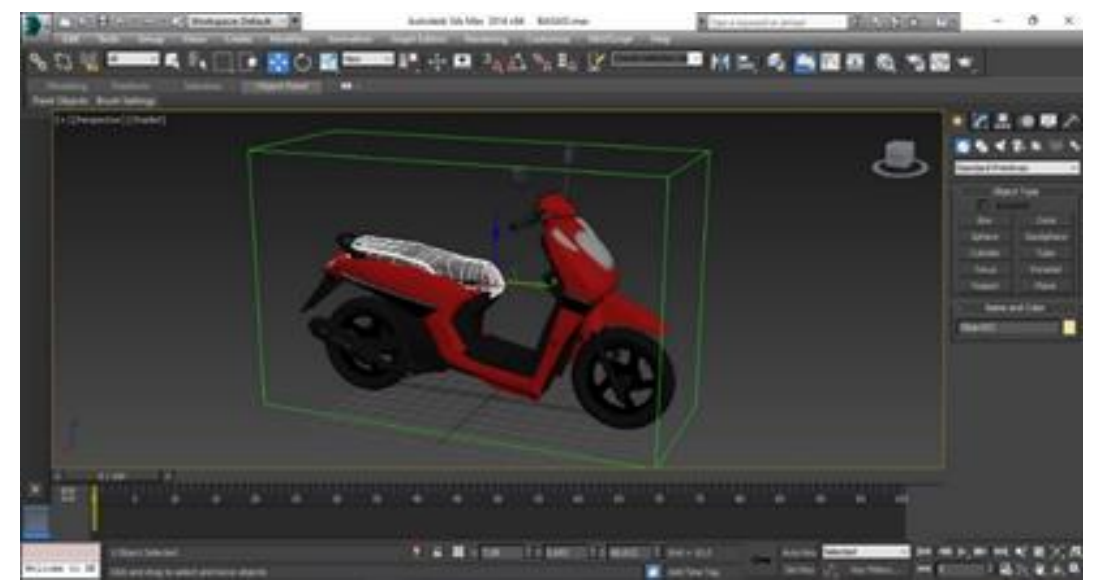

\section{2) Texturing}

Gambar 3. Tampilan Modelling Objek Motor

Tahap texturing merupakan proses pemberian warna pada objek yang telah dibuat agar memberi kesan nyata pada objek. Material yang digunakan dapat berupa gambar atau warna yang terdapat software 3Ds Max 2014.

Pada proses tekturing peneliti akan menjelaskan contoh pemberian tekstur pada karakter yang telah dibuat dengan menggunakan menu material editor dengan menekan shortcut "M", kemudian pilih material yang masih kosong kemudian pilih panel masp. Kemudian pilih warna yang diinginkan, maka akan merubah warna atau meterial yang diselidiki.

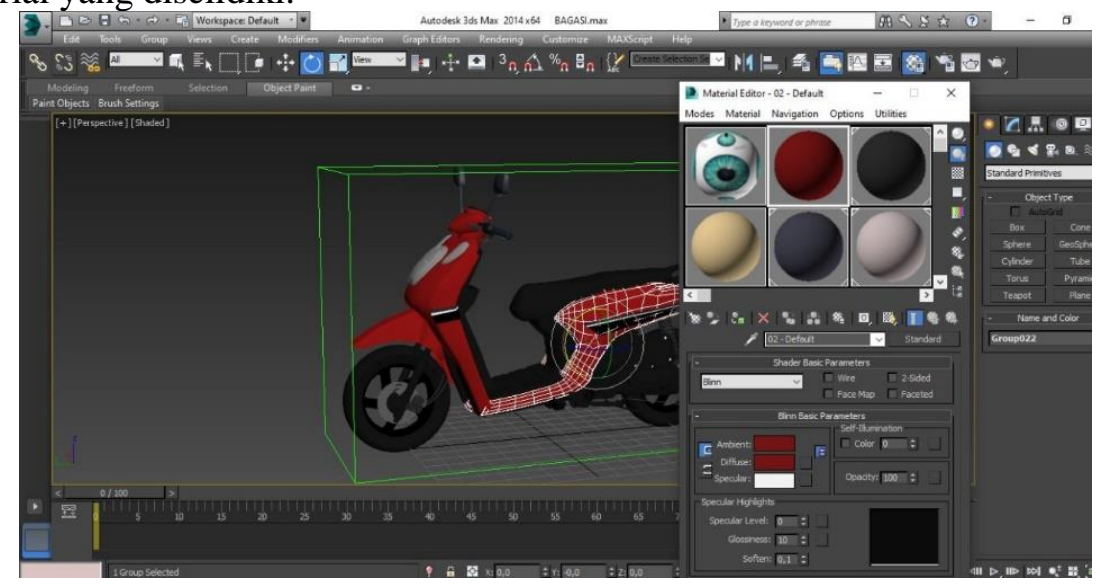

3) Lighting

Gambar 4. Tampilan Texture Objek Motor

Tahap lighting merupakan proses pemberian cahaya pada sebuah objek yang telah dibuat agar menghasilkan kesan realistis dari cahaya yang da. Peneliti hanya menggunakan satu lampu standartTargetSpot. 


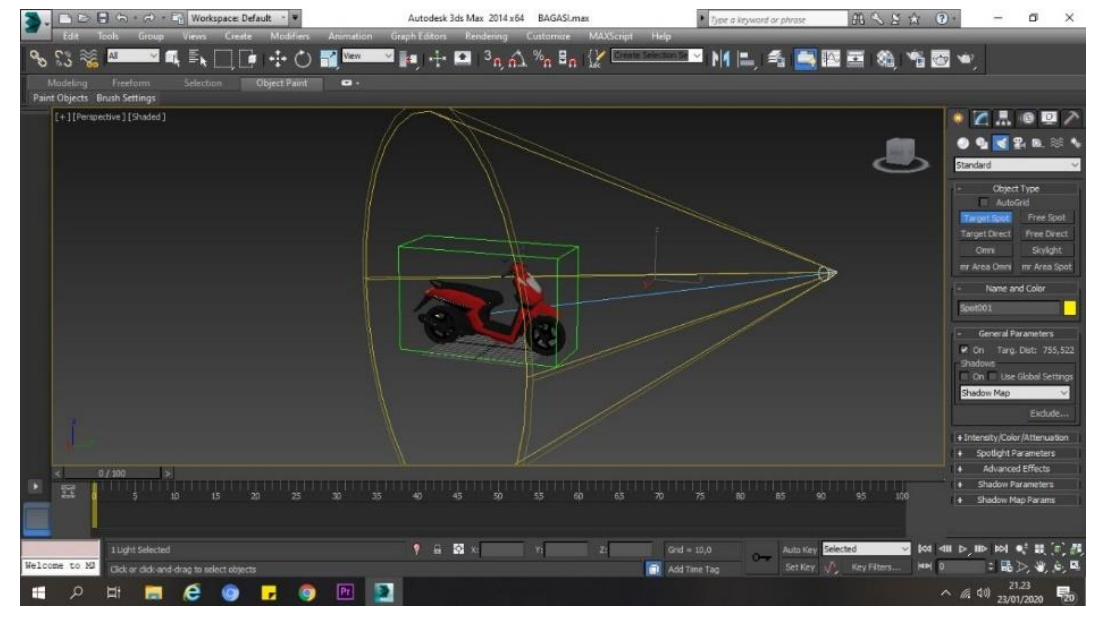

4) Rendering

Gambar 5. Tampilan Lighting Objek Motor

Tahap rendering merupakan proses menghasilkan gambar dari objek, pencahayaan dan animasi 3D. proses ini akan menghasilkan output yang merupakan proses akhir pembuatan objek.

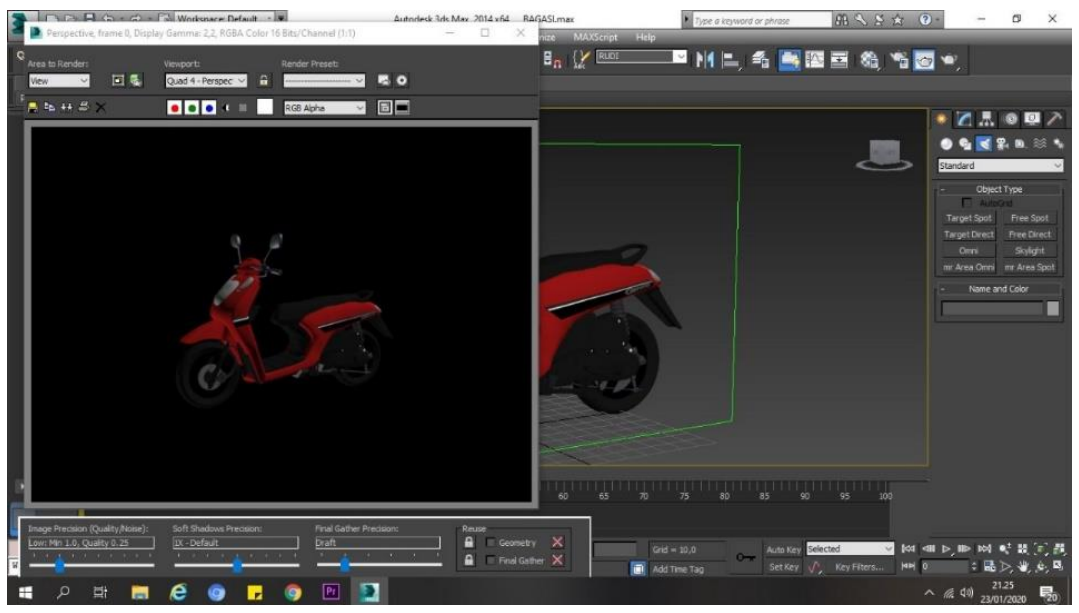

Gambar 6. Tampilan Rendering Objek Motor

b. Setting $S D K$ dan $J D K$

Pembuatan Augmented Reality dan penyatuan aplikasi media promosi pada motor Honda Genio menggunakan software Unity. Berikut adalah langkah-langkahnya:

Tahap yang pertama dilakukan adalah pembuatan scene camera, scene camera ini berfungsi untuk menampilkan objek 3D berupa Motor, serta beberapa scene lainnya seperti scene loading, scene menu, scene panduan serta beberapa tombol dan fungsi dari masing-masing tombol tersebut. Sebelum masuk ketahap pembuatan Augmented Reality yaitu buka software Unity lalu setting project-nya terlebih dahulu. 


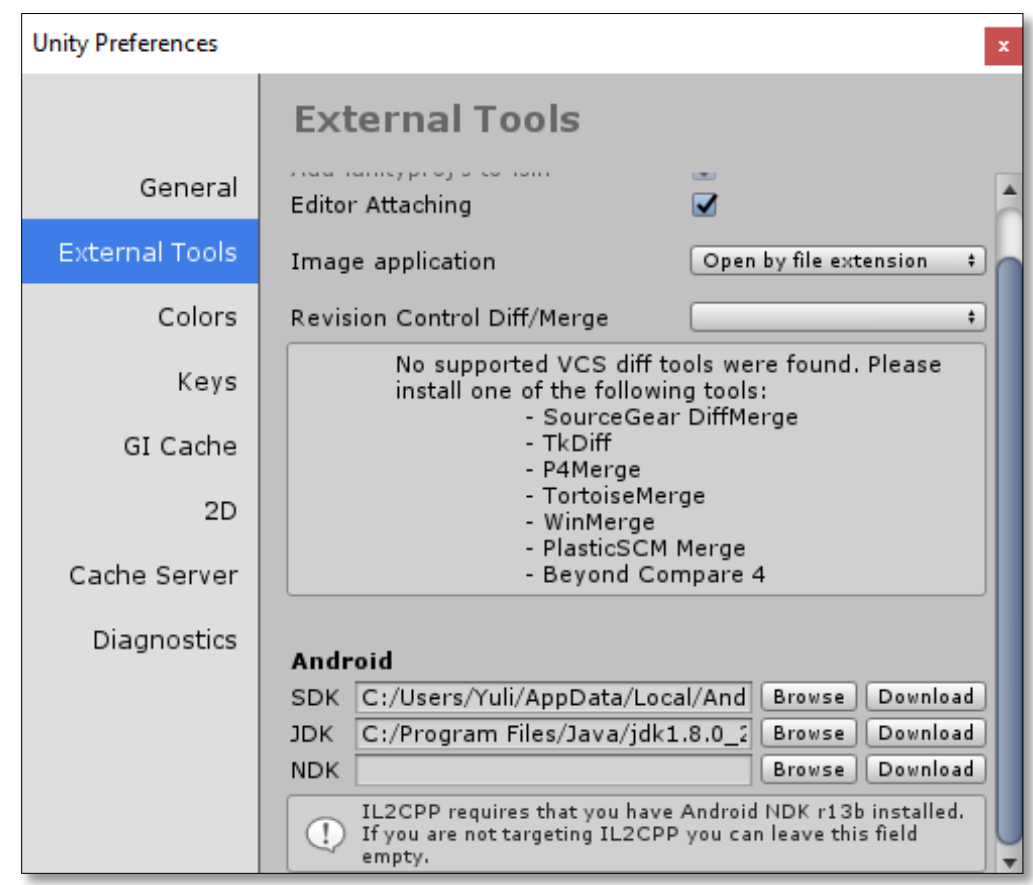

Gambar 7. Tampilan Setting SDK dan JDK

Setting SDK dan JDK ini berfungsi pada saat setalah selesai membuat project dan mengubah project tersebut supaya dapat dibangun atau build dalam bentuk apk. dengan cara masuk ke menu Edit > Preference > kemudian pilih menu External Tools dan import SDK dan JDK seperti gambar diatas.

c. Mengganti Platform Ke Android

Penggantian platform ke android berfungsi untuk project yang telah dibuat dapat di install didalam sebuah smartphone / android. Tahap yang dilakukan adalah Pilih File $>$ BuiLd Setting kemudian atur atau ganti platform ke Android > Switch Platform. Build setting juga berfungsi untuk memasukan seluruh scene kedalam daftar scene yang akan dibangun menjadikan .apk dengan cara klik Add Open Scenes kemudian pilih scene yang telah dibuat di media penyimpanan > ok.

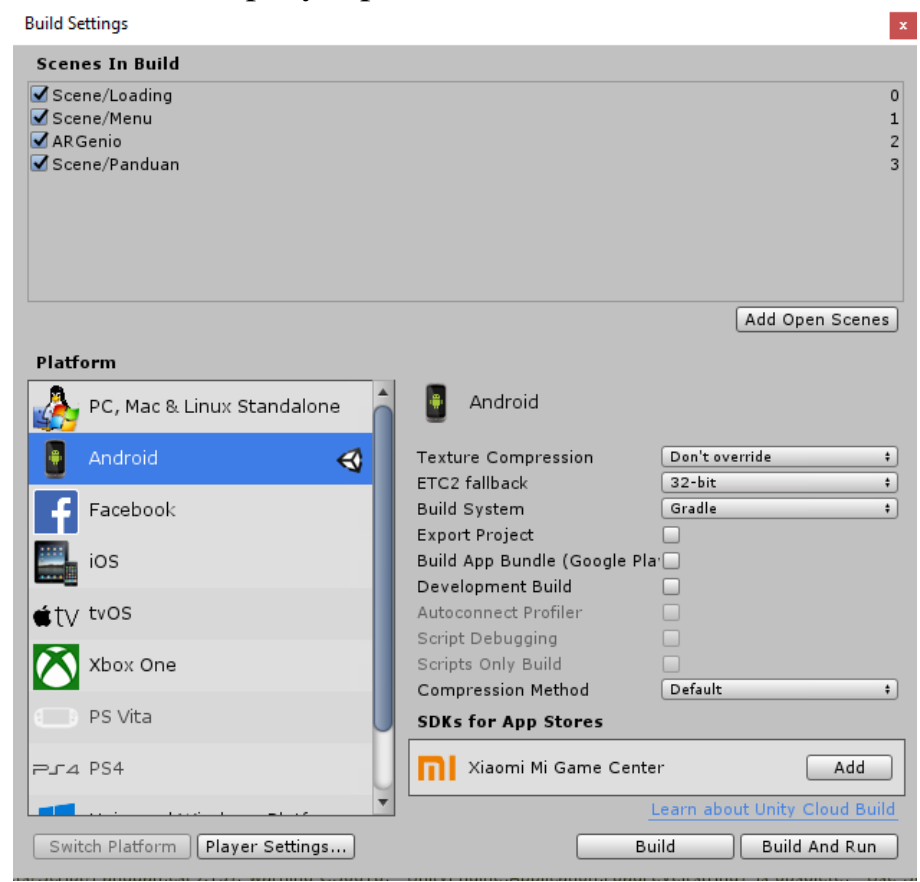

Gambar 8. Tampilan Build Setting 
d. Setting vuforia Augmented Reality

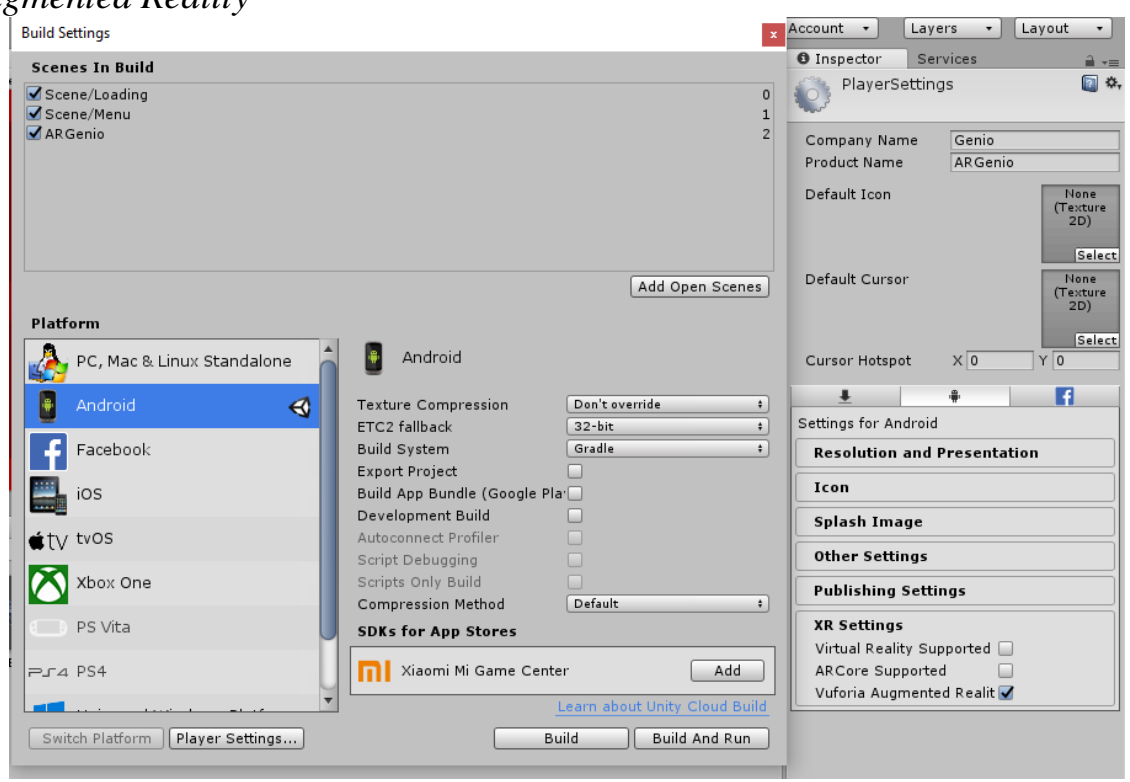

Gambar 9. Tampilan Setting Vuforia Augmented Reality

Untuk mengatur Vuforia Augmented Reality yang dilakukan adalah pergi ke Build Setting kemudian pilih Player Setting pada bagian Inspector pergi ke XR Setting kemudian pilih dan beri tanda ceklis Vuforia Augmented Reality.

e. Import Database Marker

Import database ini berfungsi untuk mendapatkan sebuah database marker yang digunakan sebagai bahan untuk scan gambar untuk menampilkan sebuah objek AR. Sebelum meng-import database ke Unity, yaitu membuat database marker terlebih dahulu.

\section{Create Database}

Database Name*
Genio
Type:
Device
Cloud
VuMark

\section{Cancel Create}

Gambar 10. Tampilan Create Database

Pertama yang dilakukan yaitu pergi ke web Vuforia Development > Task Manager > Add Database > Create Database beri nama database sesuai yang anda inginkan, lalu pilih database yang telah dibuat, lalu Add Target. Pada bagian File kita import atau pilih vuforia objek yang akan kita jadikan marker atur width lalu klik add. 


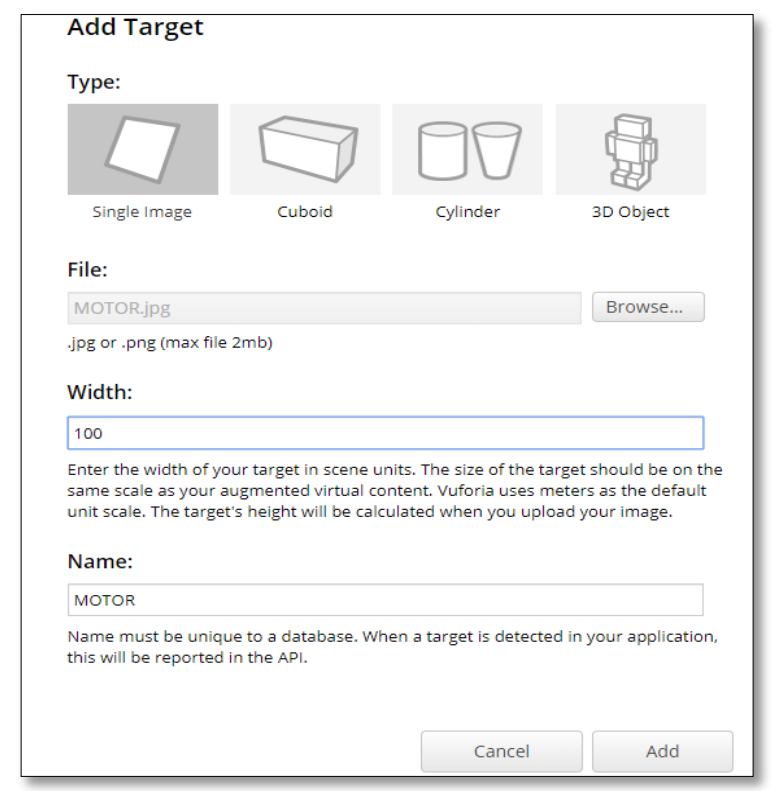

Gambar 11. Tampilan Add Target

Setelah target marker kita buat maka hasilnya akan seperti gambar dibawah. Jika ratingnya terdapat 5 bintang menandakan vuforia objek marker tersebut sangat bagus.

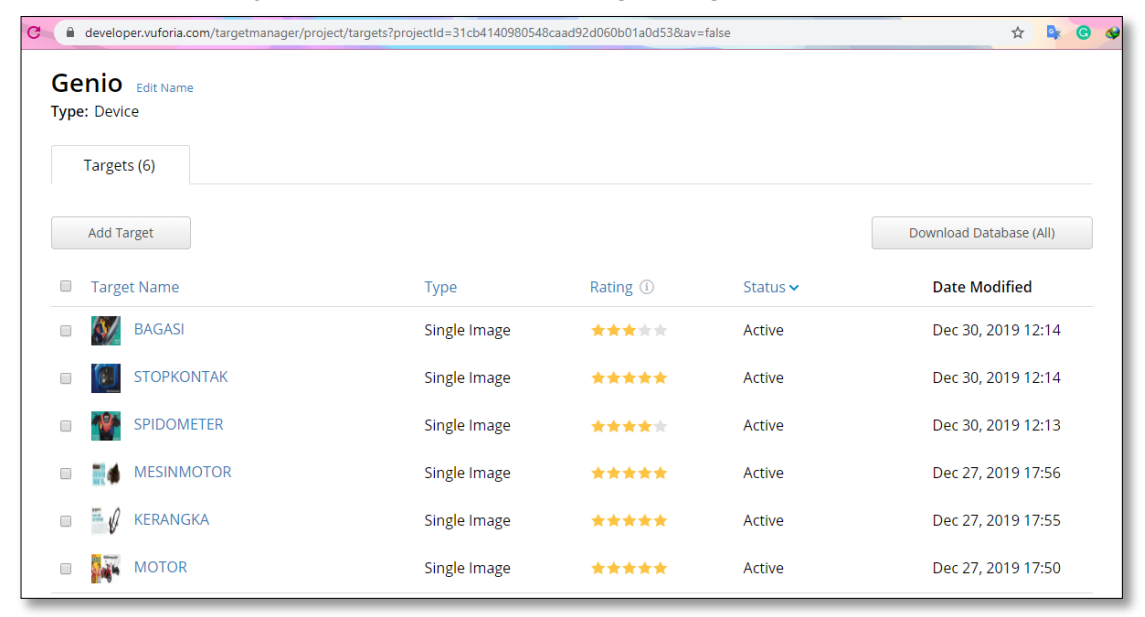

Gambar 22. Tampilan Vuforia Object Marker

Tahap selanjutnya yaitu Download Database dan atur tempat penyimpananya. Setelah Database terdownload tahap selanjutnya yaitu import Database ke Unity dengan cara klik kanan pada folder asset > import package pilih custom package kemudian pilih file Database Marker tersebut.

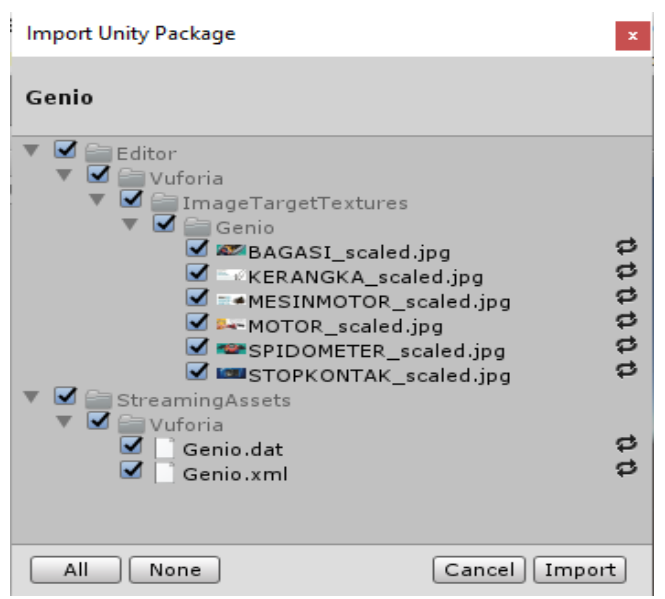

Gambar 13. Import Database Marker 


\section{f. Import License Key}

Hal yang dilakukan yaitu klik pada ARCamera > inspector > Open Vuforia Configuration. Kemudian copy License Key yang telah dibuat sebelumnya di menu Develope License Manager dan pastekan dibagian App License Key . Lalu dibagian Database pilih dan beri tanda ceklis pada nama database yang telah kita buat.

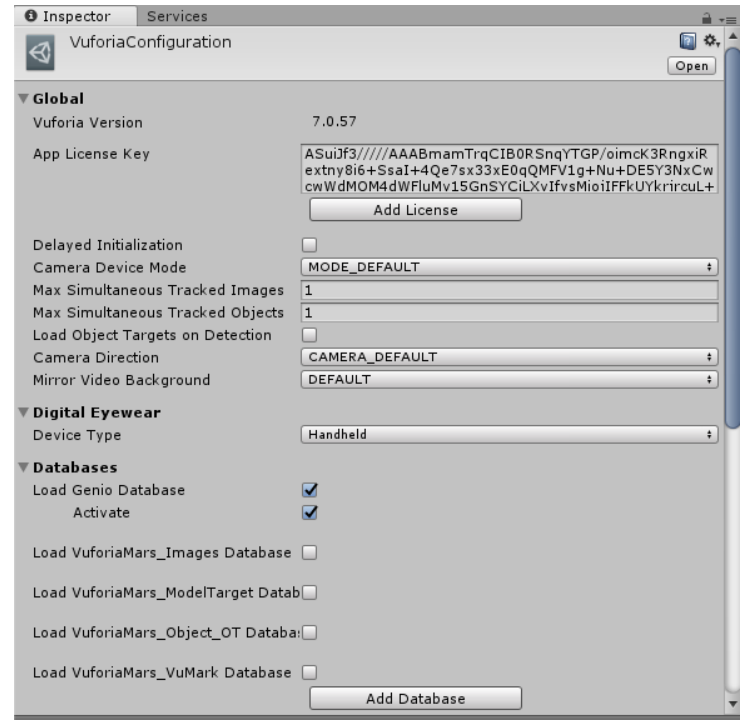

Gambar 34. Tampilan License Key Vuforia Configuration

g. Import Marker

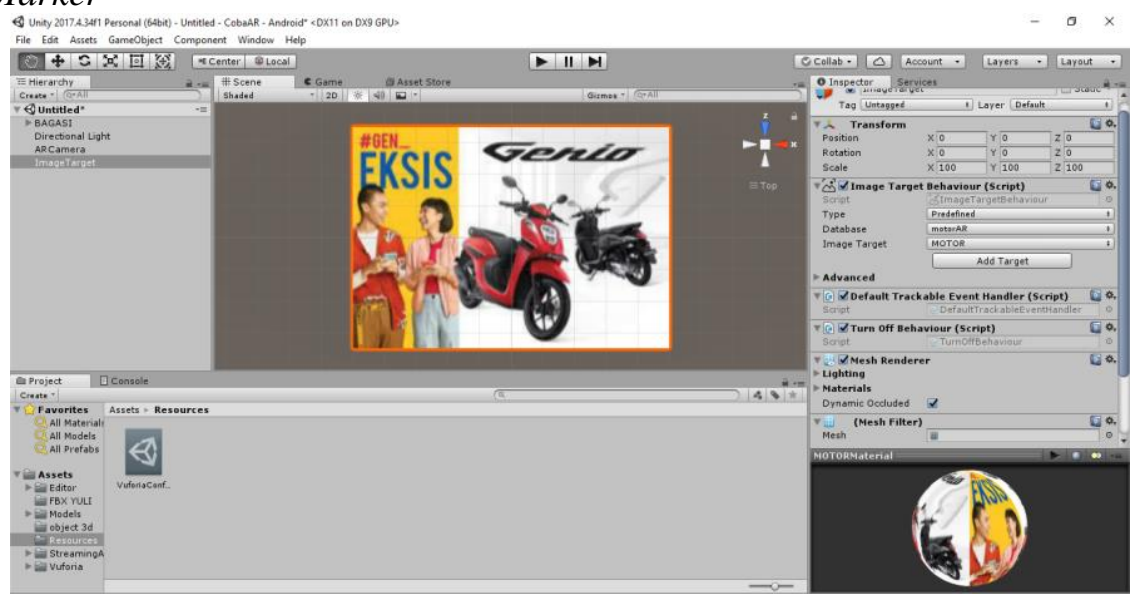

Gambar 45. Tampilan Marker

Untuk meng- import marker yang telah kita buat hal yang dilakukan yaitu dengan cara import terlebih dahulu sebuah database marker ke unity. Kemudian pada menu inspectors atur dan pilih Type, Database, dan Image Target sesuai yang dibutuhkan.

h. Membuat scene ARCamera 


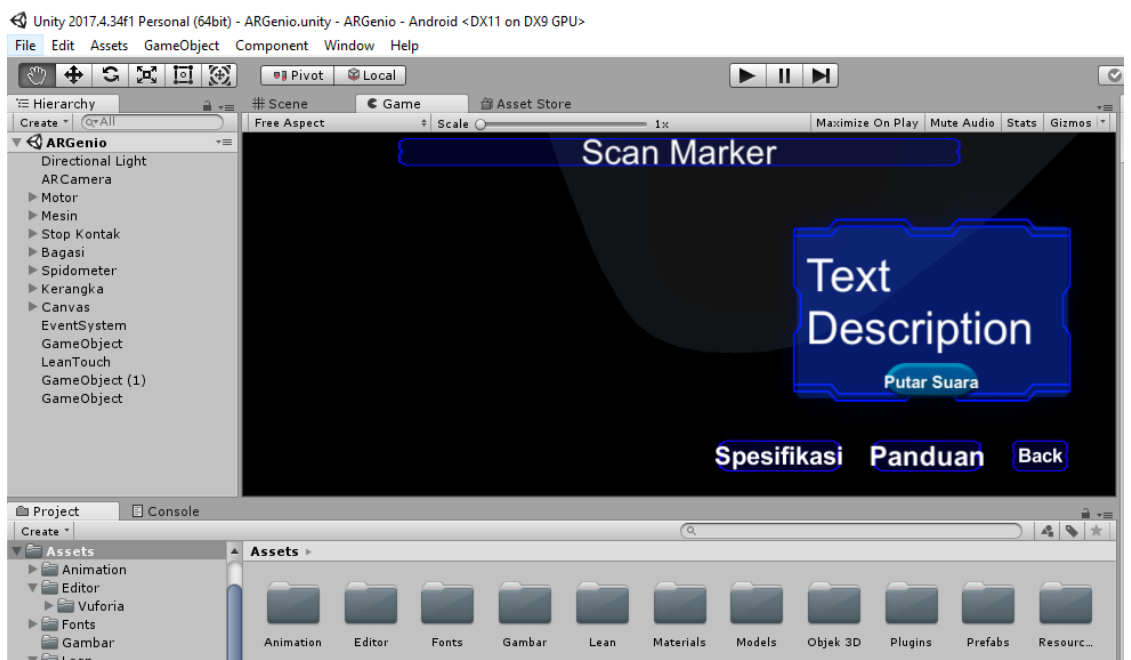

Gambar 56. Tampilan ARCamera

Pada tampilan ini berfungsi untuk menampilkan objek 3D yang telah dibuat. Hal yang dilakukan adalah klik Game Object > Vuforia > ARCamera kemudian buat desain ARCamera sesuai yang diinginkan. Untuk desain menggunakan SF UI dari Lean Touch yang dapat di unduh di asset store unity dengan cara klik windows pilih asset store kemudian di kolom pencarian ketikan Lean Touch > unduh > lalu import. Kemudian di menu Asset pilih Texturer and Sprites lalu SF UI.

i. Membuat Multi-Image Target

Multi Image Target berfungsi untuk membuat dan menampilkan lebih dari satu objek. Yang dilakukan untuk membuat Multi Image Target yaitu pada bagian Scene ARCamera buat Multi Image Target dengan klik Game Object > Vuforia > Image. Kemudian di bagian Inspector Image Target Behaviour atur Database dan Image Target yang akan digunakan. Kemudian lakukan hal yang sama kembali.

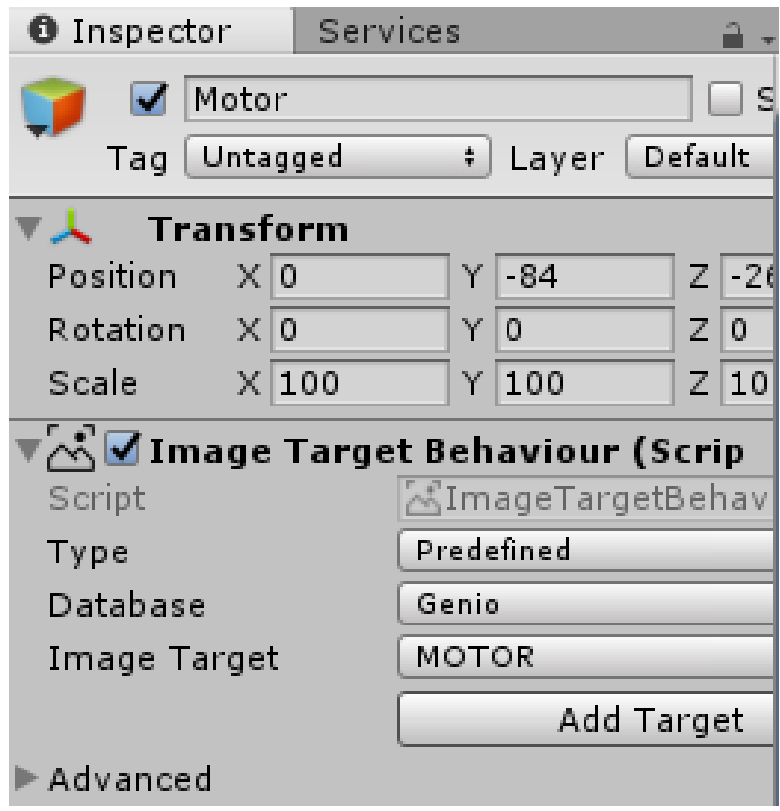

Gambar 17. Tampilan Image Target Behaviour 


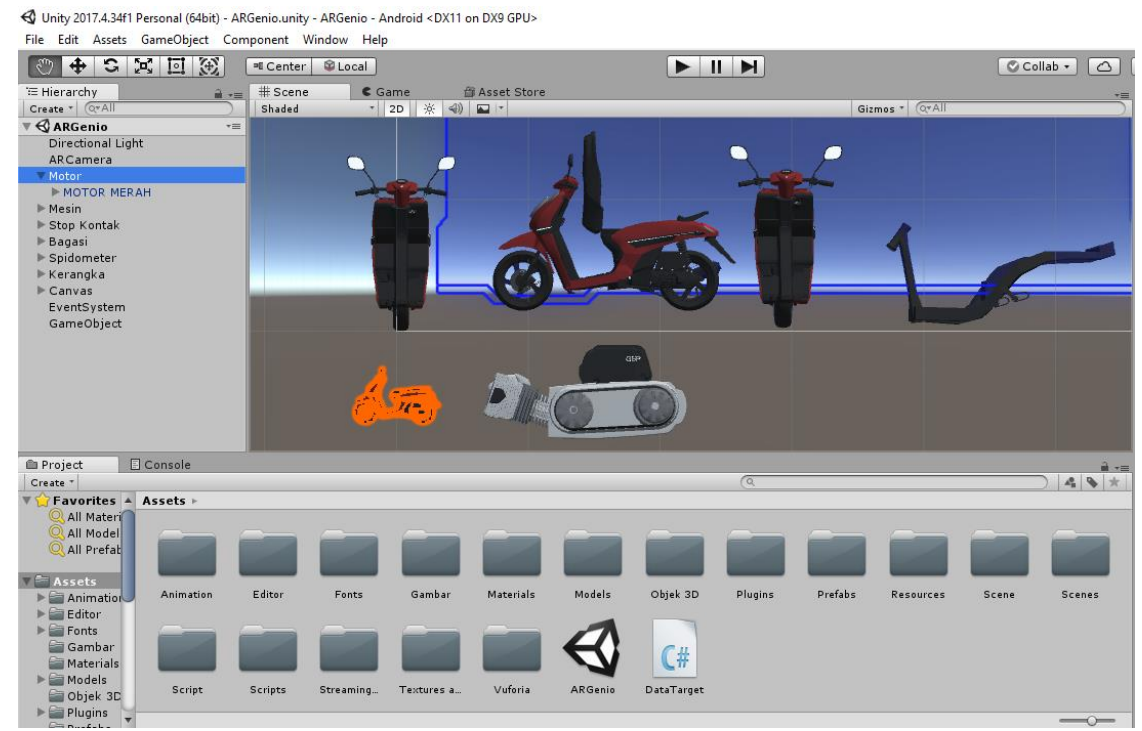

Gambar 68. Tampilan Multi Image Target

j. Membuat Scene Splash Loading

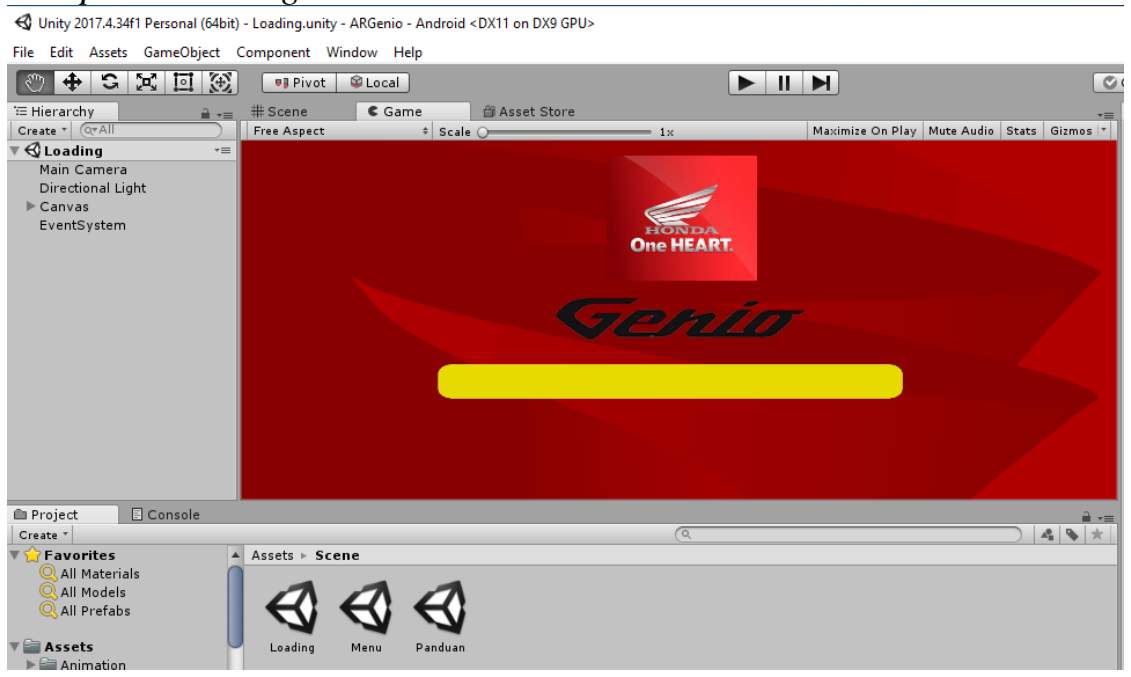

Gambar 19. Tampilan Splash Loading

Pada tampilan ini berupa proses splash loading aplikasi untuk masuk ke scene menu utama. Tahap pembuatannya sebagai berikut:

1) Klik kanan pada hirerarchy pilih canvas.

2) Masukan image dengan cara klik kanan pada hirerarchy pilih UI kemudian image, lalu atur pada bagian Rect Transform ubah custom menjadi stretch dan ganti ukuran menjadi 0 semua. Lalu ubah pada bagian source image dengan gambar yang sudah disiapkakn untuk background.

3) Tambahkan 2 image untuk membuat loading bar dan loading base, atur loading base pada bagian image script ubah image type menjadi field, ubah fil method menjadi horizontal dan ubah fil orgin menjadi left. Kemudian buat script dengan nama loading lalu drag script pada loading bar dan ubah speed pada bagian loading (script) menjadi 30.

k. Membuat Scene Menu 


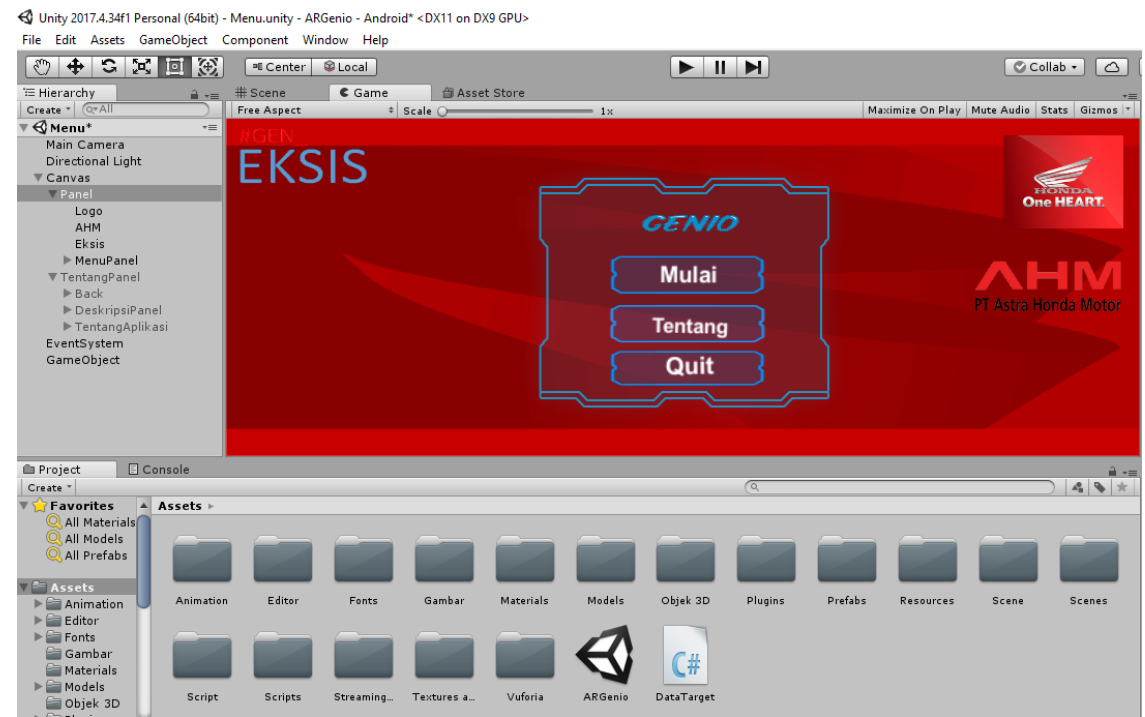

Gambar 20. Tampilan Menu

Pada scene menu utama terdapat beberapa tombol menu yang dipilih oleh pengguna sesuai kebutuhan yaitu menu mulai berfungsi untuk menampilkan objek 3D, menu tentang berfungsi untuk mengetahui apa itu AR dan mengetahui informasi identitas programmer dan informasi sosial media dari PT.Astra Honda Motor serta tombol back berfungsi untuk kembali ke menu utama.

1. Membuat Scene Menu Tentang

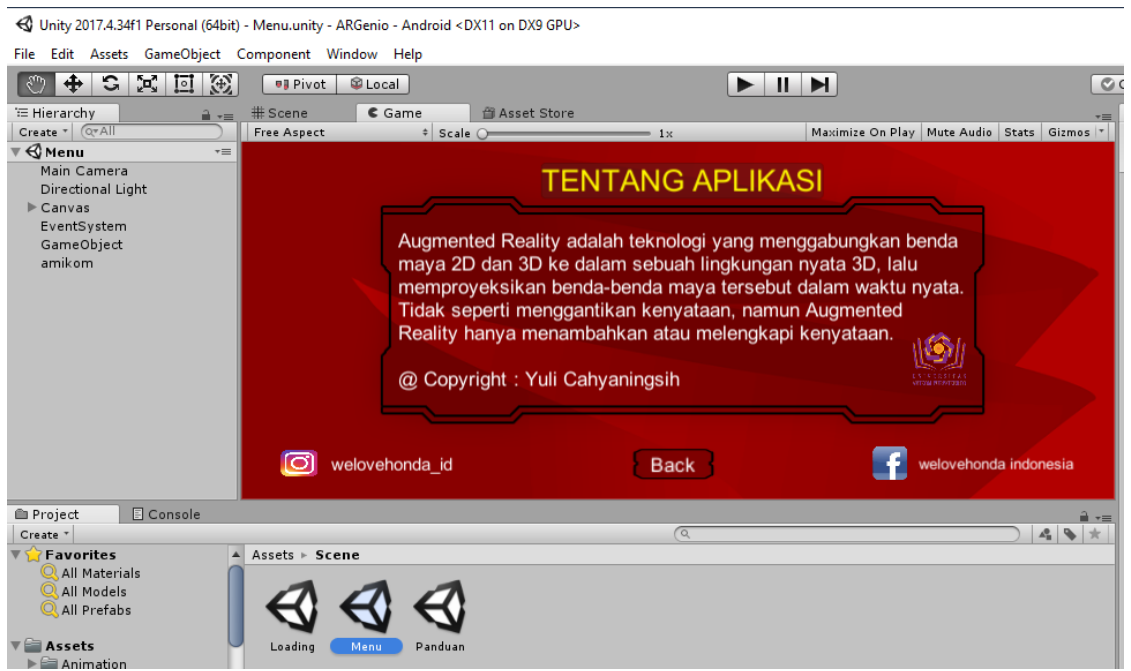

Gambar 21. Tampilan Menu Tentang

Pada scene tentang terdapat sebuah teks deskripsi tentang augmented reality dan informasi identitas dari programmer serta informasi media sosial PT.Astra Honda Motor.

m. Membuat Scene Panduan 


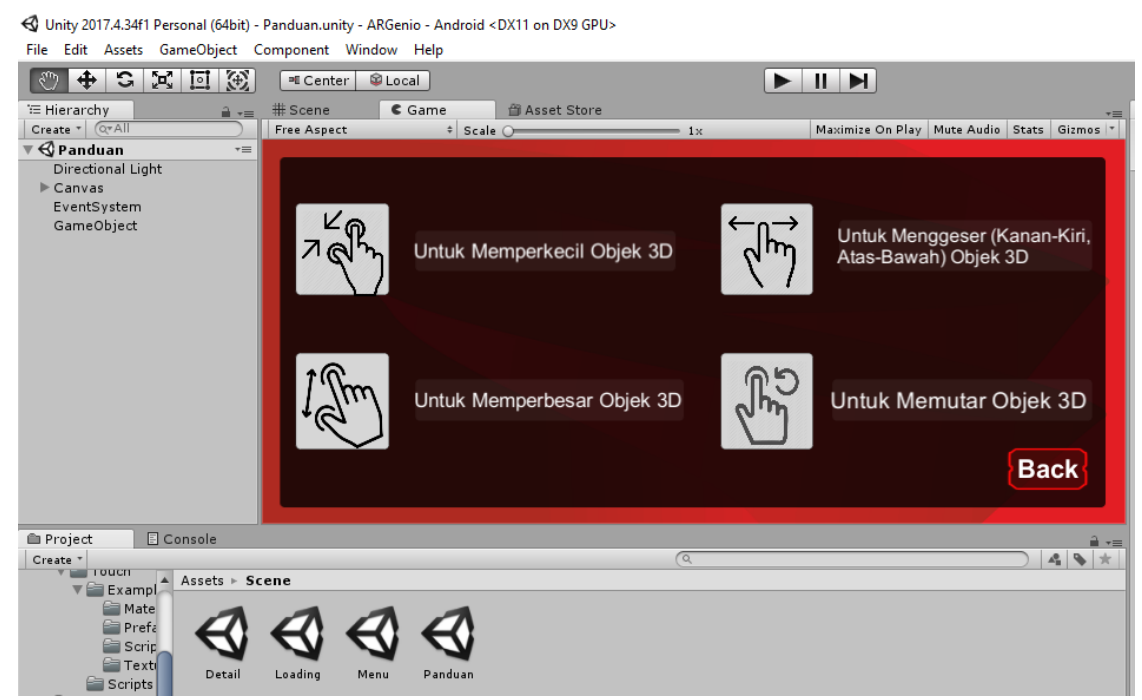

Gambar 72. Tampilan Scene Panduan

Pada tampilan scene ini berupa panduan aplikasi untuk memperkecil, memperbesar, serta untuk memutar dan menggeser objek 3D ke kanan-kiri, atas dan bawah.

n. Membuat Scene Spesifikasi

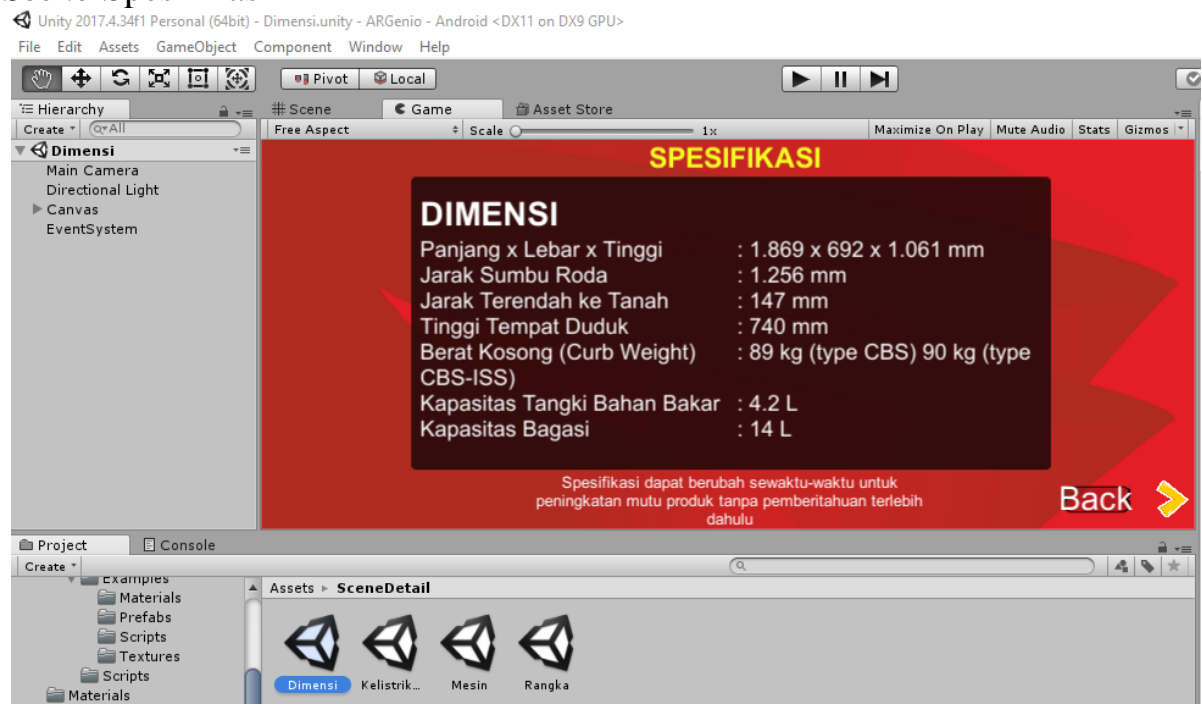

Gambar 23. Tampilan Scene Spesifikasi

Pada tampilan scene ini berupa spesifikasi berfungsi untuk mengetahui tentang spesifikasi motor Honda Genio.

o. Tampilan Player Setting

Player setting berfungsi untuk merubah sebuah Company Name dan Product Name aplikasi menjadi Genio dan ARGenio. 


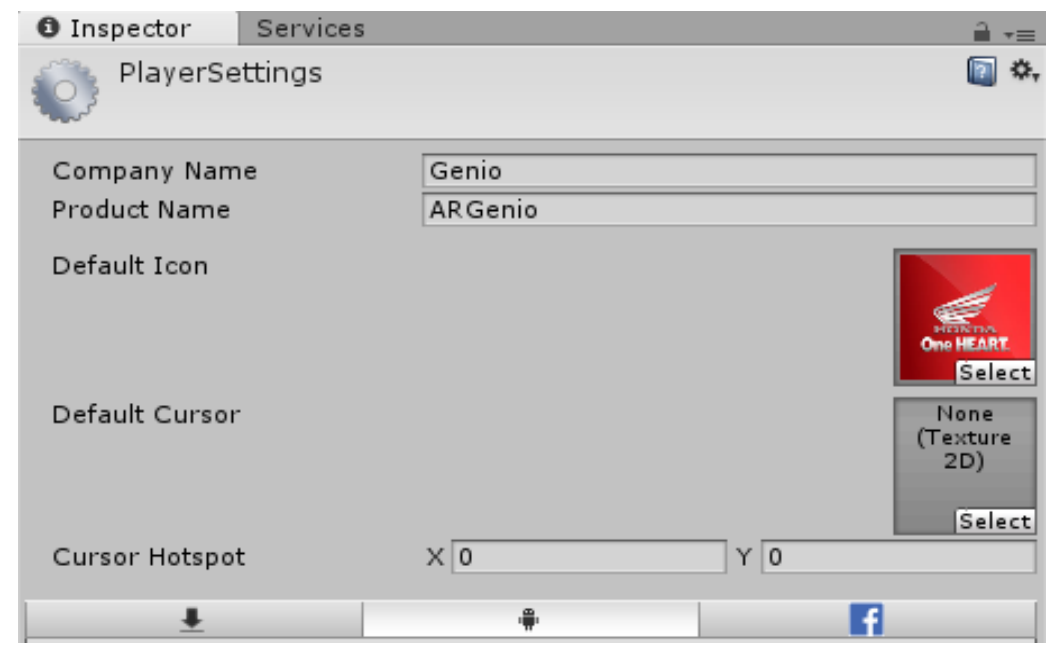

Gambar 84. Tampilan Player Setting

\section{p. Setting For Android}

Setting for android berfungsi untuk mengatur sebuah tampilan aplikasi sesuai yang dibutuhkan. Yang dibutuhlan adalah setting icon aplikasi ARGenio dengan memasukan gambar logo Honda. Kemudian atur Other Setting yang berfungsi untuk aplikasi agar dapat dibangun atau build ke device lain dengan cara menuju ke identification kemudian ubah nama pada kolom package name sesuai dengan company name dan product name pada player setting kemudian atur Minimum API Level untuk memberikan batasan pengguna device android.

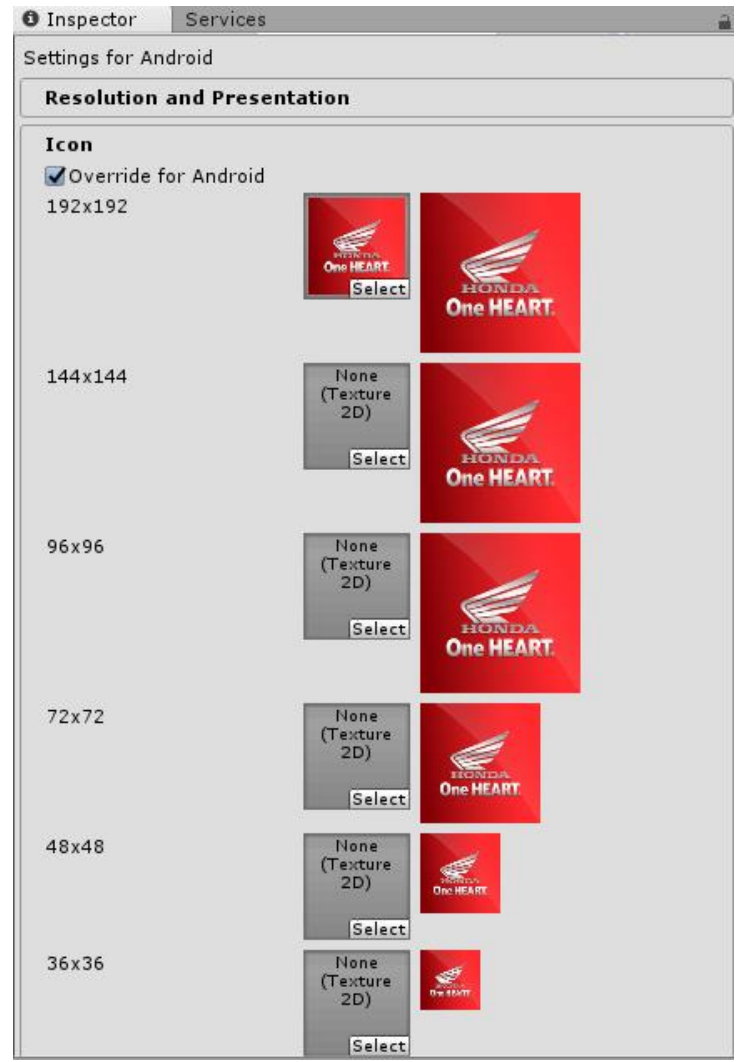

Gambar 95. Tanpilan Setting Icon 


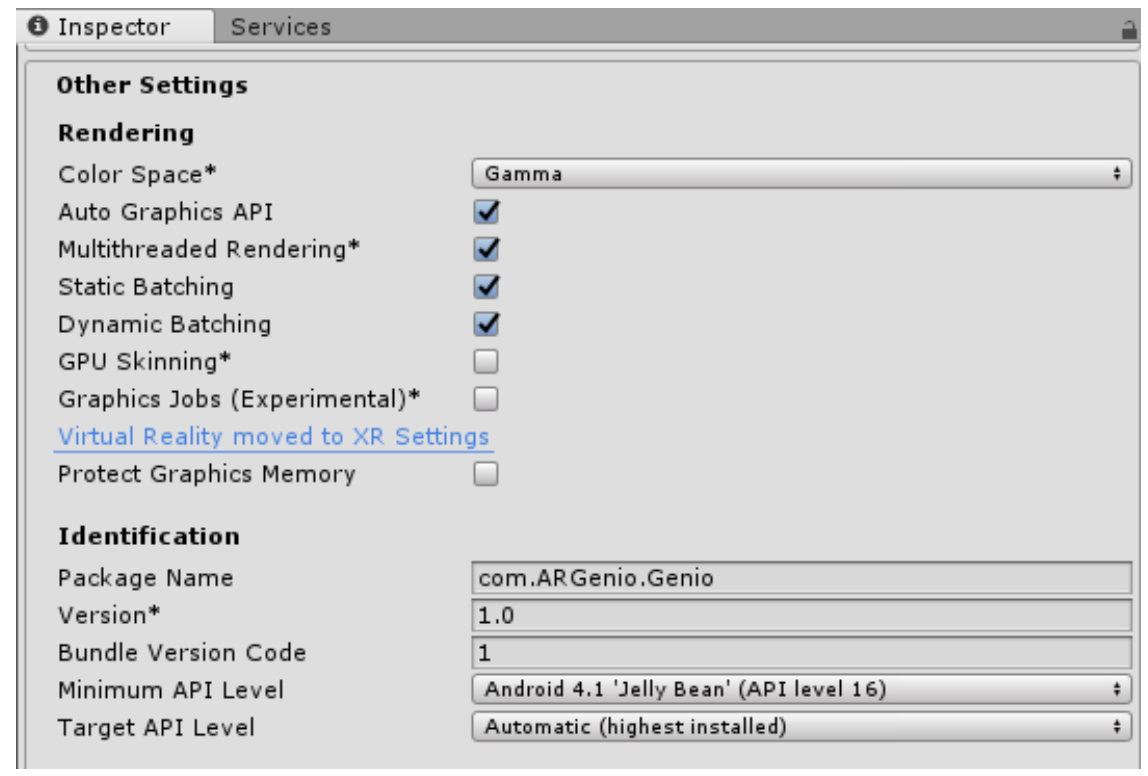

Gambar 106. Tampilan Other Setting

q. Build Aplikasi

Untuk bulid aplikasi dengan cara pergi ke bulid setting kemudian klik build dan simpan file apk di media penyimpanan lalu Ok dan tunggu hingga proses build selesai. Ada 2 tahap build yaiitu pertama loading untuk pendeteksian SDK yang kedua loading untuk Build Player.

Detecting Android SDK

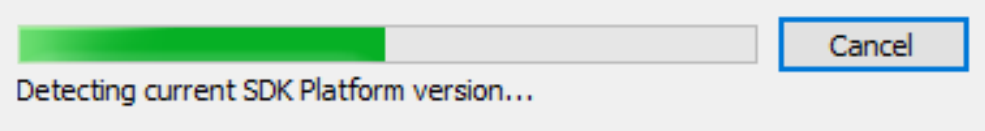

Gambar 27. Build Aplikasi

\section{Pengujian (Testing)}

Pada tahap ini dilakukan pengujian secara berkala setiap setelah menyelesaikan pembuatan aplikasi penerapan teknologi Augmented Reality pada brosur Honda Genio dengan cara menjalankan aplikasi atau program dan dengan melihat apakah ada kesalahan atau tidak pada program yang telah dibuat. Jika semua sudah berjalan dengan baik maka akan lanjut ke tahap selanjutnya yaitu distributions. Pengujian ini akan memperoleh keseluruhan fungsional aplikasi serta pengujian terhadap kamera $A R$ yang menampilkan objek $3 D$. Dalam tahapan ini dilakukan dua metode yaitu pengujian Alpha dan selanjutnya akan dilakukan pengujian Beta.

a. Pengujian Alpha

Pengujian alpha adalah salah satu strategi pengujian perangkat lunak yang paling umum digunakan dalam pengembangan perangkat lunak, hal ini dilakukan dengan tujuan agar sistem yang dikembangkan terhindar dari cacat atau kegagalan penggunaan[15].

Tabel 3. Hasil Pengujian

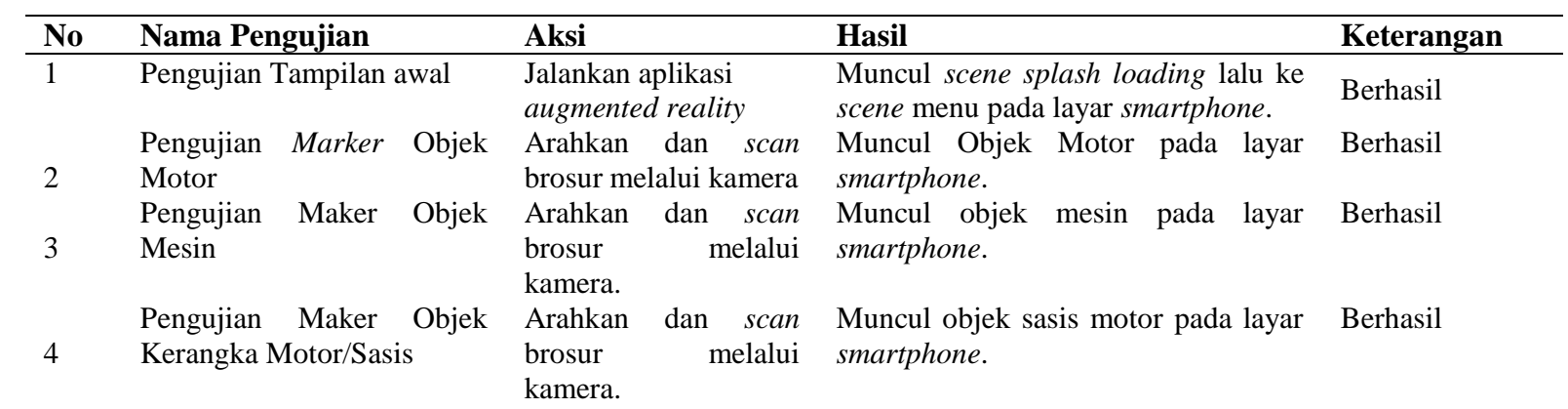




\begin{tabular}{|c|c|c|c|c|}
\hline 5 & $\begin{array}{l}\text { Pengujian Marker Objek } \\
\text { Spidometer }\end{array}$ & $\begin{array}{lr}\text { Arahkan dan scan } \\
\text { brosur }\end{array}$ & $\begin{array}{l}\text { Muncul objek spidometer pada ayar } \\
\text { smartphone. }\end{array}$ & Berhasil \\
\hline 6 & $\begin{array}{l}\text { Pengujian Marker Objek } \\
\text { Stop Kontak }\end{array}$ & $\begin{array}{lr}\text { Arahkan } & \text { dan } \\
\text { brosur } & \text { melalui }\end{array}$ & $\begin{array}{l}\text { Muncul stop kontak pada.layar } \\
\text { smartphone }\end{array}$ & Berhasil \\
\hline 7 & $\begin{array}{l}\text { Pengujian Marker Objek } \\
\text { Bagasi Motor }\end{array}$ & $\begin{array}{l}\text { Arahkan dan scan } \\
\text { brosur } \\
\text { kamera. }\end{array}$ & $\begin{array}{l}\text { Muncul objek bagasi motor pada layar } \\
\text { smartphone. }\end{array}$ & Berhasil \\
\hline 8 & Pengujian Tombol Mulai & $\begin{array}{ll} & =\text { Pilih } \\
\text { dan tekan } & \text { tombol } \\
\text { mulai } & \end{array}$ & $\begin{array}{l}\text { Muncul halaman scene ARCamera } \\
\text { pada layar smartphone. }\end{array}$ & Berhasil \\
\hline 9 & Pengujian Tombol Tentang & $\begin{array}{l}\text { Pilih dan tekan tombol } \\
\text { tentang }\end{array}$ & $\begin{array}{l}\text { Muncul scene tentang } A R, \\
\text { programming dan media Informasi } \\
\text { PT.Astra Honda Motor pada layar } \\
\text { smartphone. }\end{array}$ & Berhasil \\
\hline 10 & an Tombol Panduan & $\begin{array}{l}\text { Pilih dan tekan tombol } \\
\text { panduan }\end{array}$ & $\begin{array}{l}\text { Muncul scene tantang cara } \\
\text { penggunaan aplikasi }\end{array}$ & Berhasil \\
\hline 11 & $\begin{array}{l}\text { Pengujian } \\
\text { Spesifikasi }\end{array}$ & $\begin{array}{l}\text { Pilih dan tekan tombol } \\
\text { spesifikasi }\end{array}$ & $\begin{array}{l}\text { Muncul scene spesifikasi motor } \\
\text { Honda Genio }\end{array}$ & Berhasil \\
\hline 12 & Pengujian Tombol Back & $\begin{array}{l}\text { Pilih dan tekan } \\
\text { tombol back }\end{array}$ & $\begin{array}{l}\text { Kembali ke halaman menu / } \\
\text { sebelumnya . }\end{array}$ & Berhasil \\
\hline 13 & Pengujian Tombol Quit & $\begin{array}{l}\text { Pilih dan tekan tombol } \\
\text { quit }\end{array}$ & Keluar Aplikasi. & Berhasil \\
\hline 14 & $\begin{array}{l}\text { Pengujian Tombol Putar } \\
\text { Suara }\end{array}$ & $\begin{array}{l}\text { Pilih dan tekan tombol } \\
\text { putar suara. }\end{array}$ & $\begin{array}{l}\text { Muncul audio tentang spesifikasi } \\
\text { motor }\end{array}$ & Berhasil \\
\hline
\end{tabular}

\section{b. Pengujian Beta}

Pengujian dilakukan terhadap pengguna akhir (end user) dengan metode kuesioner. Pengujian ini dilakukan oleh orang sebagai user (pengguna). Penilaian tanggapan dari responden ini menggunakan skala likert. Menurut Sugiyono [16], Skala likert digunakan untuk mengukur sikap, pendapat, dan persepsi seseorang atau sekelompok orang tentang fenomena soasial.

Pada tahap ini responden mencoba aplikasi yang telah dibuat kemudian mereka diminta untuk mengisi kuesioner yang sudah disediakan, kuesioner berisi 5 pertanyaan, berikut hasil evaluasi kuesioner pengguna:

Tabel 4. Kuesioner.

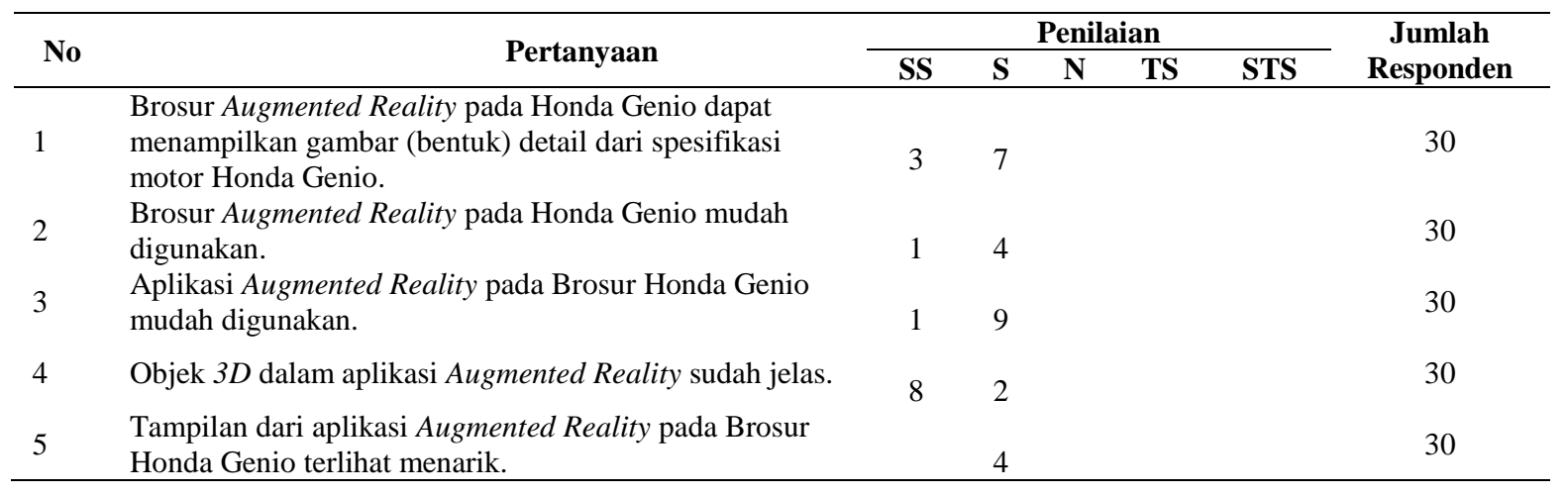

Pilihan yang diberikan kepada responden yaitu dengan menggunakan Skala likert sangat setuju, setuju, netral, tidak setuju, dan sangat tidak setuju [16], memiliki 5 respon yang memiliki nilai tersendiri. Titik respon skala likert dan bobot nilainya adalah sebagai berikut:

$\begin{array}{ll}\text { Sangat Setuju (SS) } & : 5 \\ \text { Setuju (S) } & : 4 \\ \text { Netral (N) } & : 3 \\ \text { Tidak Setuju (ST) } & : 2 \\ \text { Sangat Tidak Setuju (STS) } & : 1\end{array}$

Penilaian Responden :

Responden adalah penjawab atas pertanyaan yang diajukan untuk kepentingan penelitian. Jumlah responden yang digunakan sebagai sampel adalah 30 responden. Menurut [17], ukuran sampel yang layak 
dalam penelitian adalah 30 sampai dengan 500. Dengan jumlah 5 pertanyaan kepada responden sebanyak 5 pernyataan. Tabel 4.6 di atas menjelaskan bahwa pertanyaan ke 1 diketahui responden yang menjawab sengat setuju (x) orang, setuju berjumlah (x)orang, netral berjumlah (x) orang, tidak setuju dan sangat tidak setuju tidak ada yang memilih. Kemudian skala perhitungan dan hasil dari pengujian dilakukan menggunakan metode skala likert adalah sebagai berikut:

Menghitung skor tertinggi skala likert dengan rumus:

$\mathrm{Y}=$ Skor tertinggi $\mathrm{x}$ jumlah responden

$\mathrm{Y}=5 \times 30$

$\mathrm{Y}=150$

Selain itu menacari total skor dan index setiap pertanyaan dengan rumus sebagai berikut:

Total skor $=\mathrm{T} \times \mathrm{Pn}$

$\mathrm{T}=$ Total responden yang memilih

Pn = pilihan angka skala likert

Pertanyaan 1 diketahui responden yang menjawab Sangat Setuju 13 orang, Setuju 17 orang, Netral, Tidak Setuju dan Sangat Tidak Setuju tidak ada yang memilih maka perhitungannya menjadi:

Jumlah skor pertanyaan 1

1. Responden menjawab SS (5) $=13 \times 5=65$

2. $\quad$ Responden menjawab $S(4)=17 \times 4=68$

3. Responden menjawab N (3) $=0 \times 3=0$

4. Responden menjawab TS $(2)=0 \times 2=0$

5. Responden menjawab STS $(1)=0 \times 1=0$

Maka total skor aspek $1=65+68+0+0+0=133$

Selanjutnya mencari index $\%$

Rumus Index 1\% = TPI / Y x 100\%

$=133 / 150 \times 100 \%$

$=88 \%$

Pertanyaan 2 diketahui responden yang menjawab Sangat Setuju 11 orang, Setuju 14 orang, Netral 5 orang, Tidak Setuju dan Sangat Tidak Setuju tidak ada yang memilih maka perhitungannya menjadi:

Jumlah skor pertanyaan 2

1. Responden menjawab SS (5) $=11 \times 5=55$

2. Responden menjawab S (4) $=14 \times 4=56$

3. Responden menjawab N (3) $=5 \times 3=15$

4. Responden menjawab TS (2) $=0 \times 2=0$

5. Responden menjawab STS $(1)=0 \times 1=0$

Maka total skor aspek $2=55+56+15+0+0=126$

Selanjutnya mencari index $\%$

Rumus Index 1\% = TPI / Y x 100\%

$=126 / 150 \times 100 \%$

$=84 \%$

Pertanyaan 3 diketahui responden yang menjawab Sangat Setuju 11 orang, Setuju 19 orang, Netral, Tidak Setuju dan Sangat Tidak Setuju tidak ada yang memilih maka perhitungannya menjadi: Jumlah skor pertanyaan 3

1. Responden menjawab SS (5) $=11 \times 5=55$

2. Responden menjawab $S(4)=19 \times 4=76$

3. Responden menjawab N (3) $=0 \times 3=0$

4. Responden menjawab TS $(2)=0 \times 2=0$

5. Responden menjawab STS $(1)=0 \times 1=0$

Maka total skor aspek $3=55+76+0+0+0=131$

Selanjutnya mencari index \%

Rumus Index 1\% = TPI / Y x 100\%

$=131 / 150 \times 100 \%$

$=87 \%$

Pertanyaan 4 diketahui responden yang menjawab Sangat Setuju 18 orang, Setuju 12 orang, Netral, Tidak Setuju dan Sangat Tidak Setuju tidak ada yang memilih maka perhitungannya menjadi:

Jumlah skor pertanyaan 4

1. Responden menjawab SS (5) $=18 \times 5=90$ 
2. Responden menjawab S (4) $=12 \times 4=48$

3. Responden menjawab N (3) $=0 \times 3=0$

4. Responden menjawab TS (2) $=0 \times 2=0$

5. Responden menjawab STS $(1)=0 \times 1=0$

Maka total skor aspek $4=90+48+0+0+0=138$

Selanjutnya mencari index $\%$

Rumus Index $1 \%=\mathrm{TPI} / \mathrm{Y}$ x $100 \%$

$=138 / 150 \times 100 \%$

$=92 \%$

Pertanyaan 5 diketahui responden yang menjawab Sangat Setuju 6 orang, Setuju 24 orang, Netral, Tidak Setuju dan Sangat Tidak Setuju tidak ada yang memilih maka perhitungannya menjadi:

Jumlah skor pertanyaan 5

1. Responden menjawab SS (5) $=6 \times 5=30$

2. Responden menjawab $S(4)=24 \times 4=96$

3. Responden menjawab N (3) $=0 \times 3=0$

4. Responden menjawab TS $(2)=0 \times 2=0$

5. Responden menjawab STS $(1)=0 \times 1=0$

Maka total skor aspek $5=30+96+0+0+0=126$

Selanjutnya mencari index $\%$

Rumus Index $1 \%=\mathrm{TPI} / \mathrm{Y} \times 100 \%$

$=126 / 150 \times 100 \%$

$=84 \%$

Setelah menghitung rumus index, maka selanjutnya addalah menghitung jarak (interval) untuk mengklarifikasikan kriteria rumus yang digunakan adalah sebagai berikut:

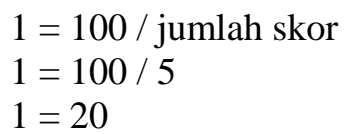

Sehingga dapat diperoleh jarak setiap kriteria adalah 20. Jarak terendah dari 0\% hingga tertinggi 100\%. Hasil klasifikasi jarak skornya menjadi:

1. Jarak $0 \%-19,99 \%-100 \%=$ Sangat Tidak Setuju

2. Jarak $20 \%-39,99 \%-100 \%$ = Tidak Setuju

3. Jarak $40 \%-59,99 \%-100 \%=$ Netral

4. Jarak $60 \%-79,99 \%-100 \%=$ Setuju

5. Jarak $80 \%-100 \%-100 \%=$ Sangat Setuju

Tabel 7. Hasil Akhir Pengujian

\begin{tabular}{ccl}
\hline Pertanyaan & Index & Keterangan \\
\hline 1 & $88 \%$ & Sangat Setuju \\
2 & $84 \%$ & Sangat Setuju \\
3 & $87 \%$ & Sangat Setuju \\
4 & $92 \%$ & Sangat Setuju \\
5 & $84 \%$ & Sangat Setuju \\
\hline
\end{tabular}

Dari Tabel 7. menunjukan hasil akhir pengujian "Penerapan Teknologi Augmented Reality Pada Brosur Honda Genio Berbasis Android" dapat diambil nilai rata-rata sebagai berikut:

Rata-rata $=(88 \%+84 \%+87 \%+92 \%+84 \%) / 5=87 \%$

Jadi rata-rata rumus index dari 30 orang atau responden sebesar $87 \%$, dan termasuk dalam kategori Sangat Setuju. Yang berarti aplikasi Augmented Reality pada brosur Honda Genio dapat menampilkan gambar (bentuk) detail dari spesifikasi motor Honda Genio.

\section{Pendistribusian (Distribution)}

Setelah melalui berbagai macam tahap dan sudah dinyatakan lulus uji, tahap berikutnya adalah distribusi. Pada tahap ini aplikasi sebagai media promosi Honda Genio akan melakukan proses pendistribusian, yang dimana aplikasi disimpan dalam bentuk file.apk. Kemudian master file.apk ini didistribusikan secara langsung melalui antar perangkat atau smartphone berbasis android menggunakan Bluetooth. 


\section{Kesimpulan}

Peneliti telah berhasil membuat aplikasi teknologi Augmented Reality pada brosur Honda Genio berbasis Android untuk melengkapi media promosi di Astra Motor Majenang, Aplikasi Augmented Reality sebagai media promosi pada brosur Honda Genio berbasis Android ini menampilkan visualisasi objek motor, mesin, kerangka, spidometer, stop kontak, bagasi motor serta menampilkan spesifikasi dalam bentuk teks dan audio. Dan Berdasarkan dari hasil pengujian Alpha Test pada Tabel 5. menghasilkan sistem yang dikembangkan terhindar dari cacat atau kegagalan penggunaan. Sedangkan hasil dari pengujian Beta Test pada Tabel 6. yang dilakukan dengan melibatkan 30 responden dengan mengajukan 5 pertanyaan, $87 \%$ menjawab sangat setuju hal ini menunjukan bahwa aplikasi Augmented Reality untuk melengkapi media promosi pada brosur Honda Genio berbasis Android dapat menampilkan gambar (bentuk) detail spesifikasi dari motor Honda Genio bagi konsumen.

\section{References}

[1]. Susanto, T. D. (2017). Sukses mengelola layanan teknologi informasi informasi dan kiat lulus ujian sertifikasi itil fondation. Surabaya: Asosiasi Sistem Informasi Indonesi (AISINDO).

[2]. Macmanroe. (2019). Teknologi informasi: pengertian, fungsi, komponen, dan tujuannya. Diambil dari https://www.maxmanroe.com/vid/teknologi/teknologi-informasi.html, diakses pada tanggal 11 Desember 2019

[3]. Pamoedji, A. K., Maryuni., dan Sanjaya, R. (2017). Mudah membuat game Augmented Reality (Ar) dan Virtual Reality (Vr) dengan Unity 3D. Jakarta: Elex Media Komputindo

[4]. Prabowo, A. Z., Satoto, K. I., dan Martono, K. T. (2016). Perancangan dan implementasi Augmented Reality sebagai media promosi penjualan perumahan. Jurnal Teknologi Dan Sistem Komputer, 3(1), 161-170.

[5]. Hadi, F., Permana, R., dan Yulanda, S. (2018). Penerapan Augmented Reality pada brosur Yamaha Tjahaja Baru untuk promosi berbasis Android. Majalah Ilmiah, 25(1), 1-8.

[6]. Abdullah, D., Sani, A., dan Hasan, A. (2019). Pemanfaatan teknologi Augmented Reality pada media pengenalan bangunan bersejarah rumah kediaman Bung Karno Bengkulu berbasis Android. Pseudocode, 5(2), 21-29.

[7]. Lengkong, H. N., Sinsuw, A. A. E., dan Lumenta, A. S. M. (2015). Perancangan penunjuk rute pada kendaraan pribadi menggunakan aplikasi Mobile Gis berbasis Android yang terintegrasi pada Google Maps. E-Journal Teknik Elektro Dan Komputer, 4(2), 18-25.

[8]. Lenurra, F., Pratiwi, D. (2017). Penerapan teknologi Augmented Reality sebagai media promosi apartemen dengan metode Markerless. Citec Jurnal, 2(1), 77-83.

[9]. Sulaeman, F. S., dan Putri, N. D. (2019). Pemanfaatan teknologi Augmented Reality Interior dan Eksterior mobil sebagai media promosi pada mobil Honda. Jurnal IKRA-ITH Informatka, 3(1), 6369.

[10]. Bagus, I., dan Mahendra, M. (2016). Implementasi Augmented Reality (AR) menggunakan Unity 3D dan Vuforia Sdk. Jurnal Ilmiah Ilmu Komputer, 9(1), 1-5.

[11].Riyanto, dan S. R, S. (2015). Pemanfaatan Augmented Reality pada media pembelajaran interaktif peredaran Planet Utilization Of Augmented Reality in Interactive Learning Media Of Planet Revolution. Juita, 3(11), 187-192.

[12].Rumajar, R., Lumenta, A., Sugiarso, B. A., dan Unsrat, J. T. E. (2015). Perancangan brosur interaktif berbasis Augmented Reality. E-Journal Teknik Elektro Dan Komputer, 4(6), 1-9.

[13].Binanto, (2010). Multimedia digital - dasar teori dan pengembangannya. Yogyakarta: Andi Ofset

[14].Mustika, M., Sugara, E. P. A., dan Pratiwi, M. (2018). Pengembangan media pembelajaran interaktif dengan menggunakan metode multimedia Development Life Cycle. Jurnal Online Informatika, 2(2), 121-126.

[15].Wahyudi, R., Utami, E., \& Arief, M. R. (2016). Sistem Pakar E-Tourism Pada Dinas Pariwisata D.I.Y Menggunakan Metode Forward Chaining. Jurnal Ilmiah DASI, 17(2), 67-75. 
[16].Sugiyono, (2018). Metode penelitian kuantitatif. Bandung: Alfabeta

[17].Sugiyono, (2012). Metode penelitian kuantitatif kualitatif dan R dan D. Bandung: Alfabeta 